ORNL/TM-2014/666

\title{
Final Review of the Campbell Creek Demonstrations Showcased by Tennessee Valley Authority
}

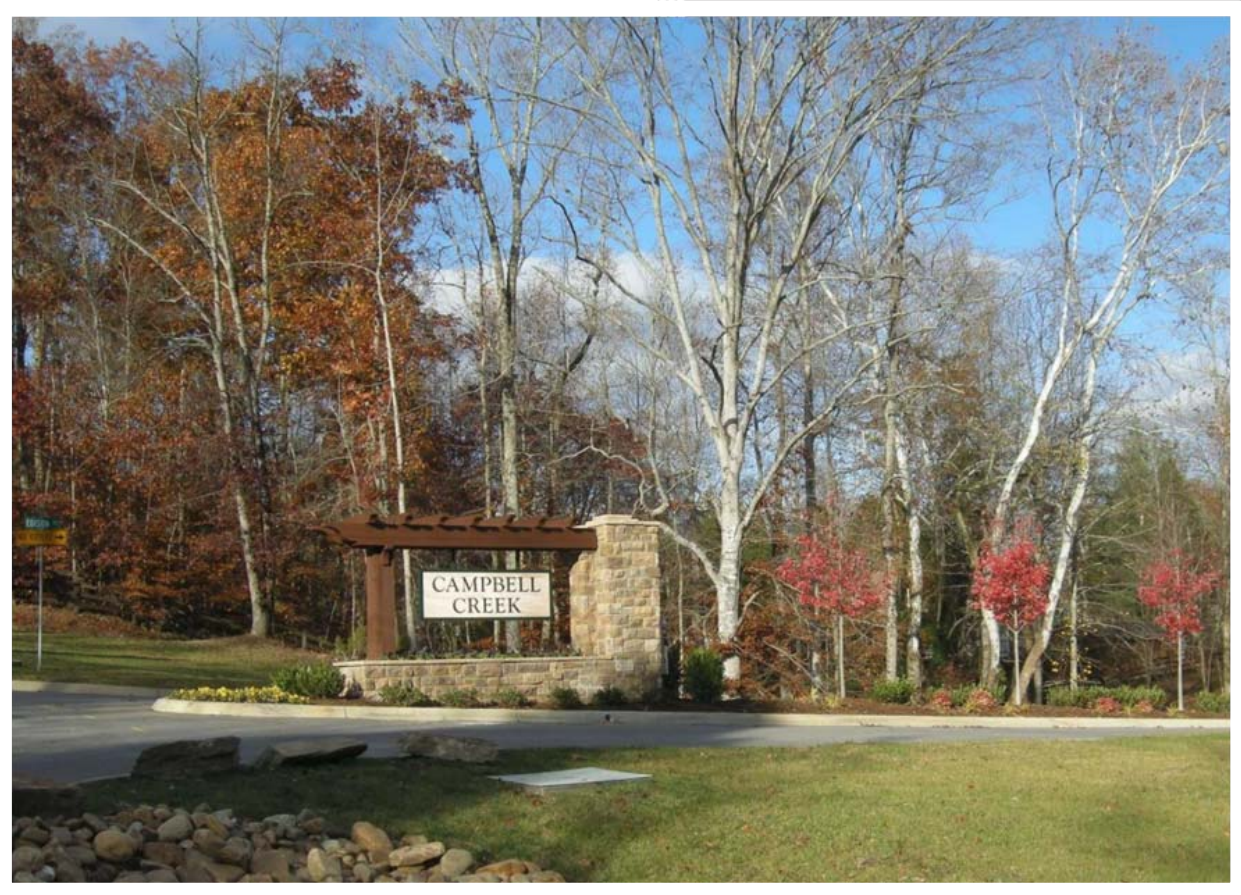

Approved for public release; distribution is unlimited.
Philip R. Boudreaux Anthony C. Gehl Roderick K. Jackson Giannate Khowailed, SRA International William (Bill) Miller Jeffrey Munk Joshua New

June 2015 


\section{DOCUMENT AVAILABILITY}

Reports produced after January 1, 1996, are generally available free via US Department of Energy (DOE) SciTech Connect.

Website http://www.osti.gov/scitech/

Reports produced before January 1, 1996, may be purchased by members of the public from the following source:

National Technical Information Service

5285 Port Royal Road

Springfield, VA 22161

Telephone 703-605-6000 (1-800-553-6847)

TDD 703-487-4639

Fax 703-605-6900

E-mail info@ntis.gov

Website http://www.ntis.gov/help/ordermethods.aspx

Reports are available to DOE employees, DOE contractors, Energy Technology Data Exchange representatives, and International Nuclear Information System representatives from the following source:

Office of Scientific and Technical Information

PO Box 62

Oak Ridge, TN 37831

Telephone 865-576-8401

Fax 865-576-5728

E-mail reports@osti.gov

Website http://www.osti.gov/contact.html

This report was prepared as an account of work sponsored by an agency of the United States Government. Neither the United States Government nor any agency thereof, nor any of their employees, makes any warranty, express or implied, or assumes any legal liability or responsibility for the accuracy, completeness, or usefulness of any information, apparatus, product, or process disclosed, or represents that its use would not infringe privately owned rights. Reference herein to any specific commercial product, process, or service by trade name, trademark, manufacturer, or otherwise, does not necessarily constitute or imply its endorsement, recommendation, or favoring by the United States Government or any agency thereof. The views and opinions of authors expressed herein do not necessarily state or reflect those of the United States Government or any agency thereof. 
Energy and Transportation Science Division

\title{
FINAL REVIEW OF THE CAMPBELL CREEK DEMONSTRATIONS SHOWCASED BY TENNESSEE VALLEY AUTHORITY
}

\author{
Philip R. Boudreaux \\ Anthony C. Gehl \\ Roderick K. Jackson \\ Giannate Khowailed, SRA International \\ William (Bill) Miller \\ Jeffrey Munk \\ Joshua New \\ Approved for public release; distribution is unlimited. \\ Date Published: June 2015 \\ Prepared by \\ OAK RIDGE NATIONAL LABORATORY \\ Oak Ridge, Tennessee 37831-6283 \\ managed by \\ UT-BATTELLE, LLC \\ for the \\ US DEPARTMENT OF ENERGY \\ under contract DE-AC05-00OR22725
}





\section{CONTENTS}

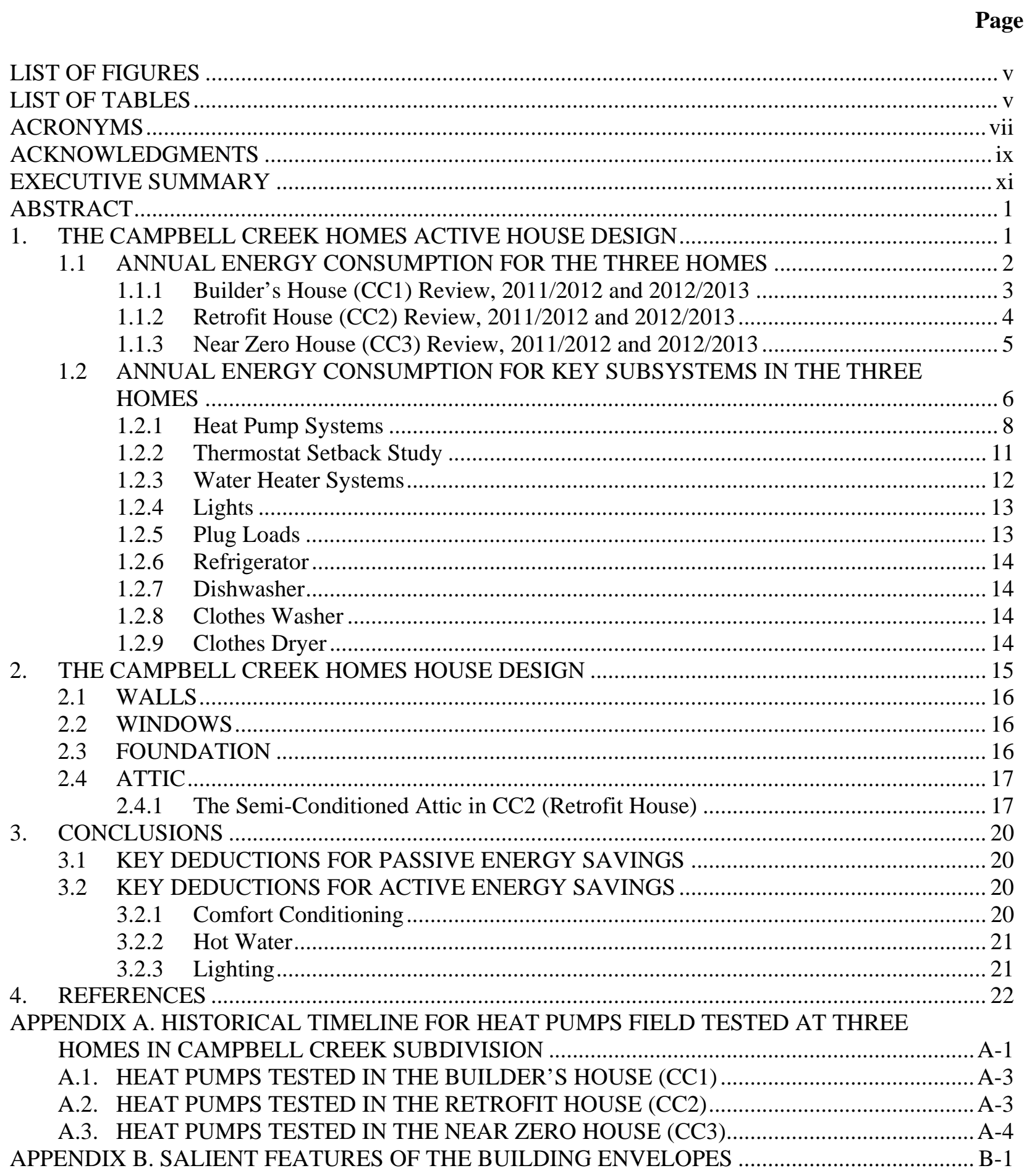





\section{LIST OF FIGURES}

Figure

Fig. 1. Map for the layout of CC1, CC2 and CC3 test homes in the Campbell Creek Subdivision. ............ 2

Fig. 2. Timeline for all the heat pumps field tested at the Campbell Creek homes. ................................... 3

Fig. 3. Breakdown of annual energy used by the CC1 home for the time period Oct. 1, 2011 through

Sep. 30, 2012 and the time period Oct. 1, 2013 through Sep. 30, 2014................................... 4

Fig. 4. Breakdown of annual energy used by the CC2 home for the time period Oct. 1, 2011 through

Sep. 30, 2012 and the time period Oct. 1, 2013 through Sep. 30, 2014................................. 5

Fig. 5. Breakdown of annual energy used by the CC3 home for the time period Oct. 1, 2011 through

Sep. 30, 2012 and the time period Oct. 1, 2013 through Sep. 30, 2014 ................................... 6

Fig. 6. Annual energy used by the heat pumps in the builder's house (CC1). The data spans from

Dec. 2011 to Sep. 2012 for the original single-stage heat pumps, and from Dec. 2012 to

Sep. 2013 for the variable capacity heat pumps.

Fig. 7. Resistance heat use in the builder's home (CC1) with the original single-speed heat pumps and also with the Carrier Greenspeed ${ }^{\mathrm{TM}}$ variable-speed air-source heat pumps. Data is from the same time periods shown in Fig. 3.

Fig. 8. The $24 \mathrm{~h} \mathrm{~kW}$ profile on the day that had maximum peak hour usage in July 2010.

Fig. 9. Measured daily heat pump energy for setback schedules compared to control being a fixed $76^{\circ} \mathrm{F}$ schedule for tests conducted during June 2011............................................................. 12

Fig. 10. Display of the apparatus used to open and close the refrigerator and freezer doors...................... 14

Fig. 11. Front view of the retrofit (CC2) home as viewed from the Hillman Rd...................................... 15

Fig. 12. The floor plans are displayed for the first floor and the second floor of the retrofit (CC2)

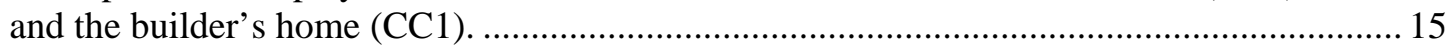

Fig. 13. Foundation insulation applied to the Near Zero house (CC3) ..................................................... 17

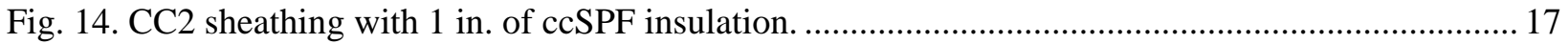

Fig. A.1. Timeline for all the heat pumps field tested at the Campbell Creek homes. ............................ A-3

\section{LIST OF TABLES}

\section{Table}

Table 1. HERS rating, infiltration rates and construction costs for FY 2012 .......................................... 2

Table 2. Annual energy (kWh) report from Oct. 1, 2011 through Sep. 30, 2012 ..................................... 6

Table 3. Annual energy use, operating costs from October 1, 2011 through September30, 2012 and initial equipment cost 



\section{ACRONYMS}

$\begin{array}{ll}\text { ACH } & \text { air exchange rate } \\ \text { ccSPF } & \text { closed cell spray polyurethane foam insulation } \\ \text { DHW } & \text { domestic hot water } \\ \text { Dish W } & \text { dish washer } \\ \text { ECM } & \text { electrically commutated motor } \\ \text { EF } & \text { energy factor } \\ \text { EPRI } & \text { Electric Power Research Institute } \\ \text { HERS } & \text { home energy rating score } \\ \text { HP } & \text { heat pump } \\ \text { HPWH } & \text { heat pump water heater } \\ \text { HSPF } & \text { heating seasonal performance factor } \\ \text { LF } & \text { load factor } \\ \text { NFRC } & \text { National Fenestration Rating Council } \\ \text { ocSPF } & \text { open cell spray polyurethane foam insulation } \\ \text { OSB } & \text { oriented strand board } \\ \text { Plugs } & \text { electrical plug loads } \\ \text { RESNET } & \text { Residential Energy Services Network } \\ \text { SEER } & \text { seasonal energy efficiency ratio } \\ \text { SHR } & \text { sensible heat ratio } \\ \text { SHW } & \text { solar hot water } \\ \text { TV } & \text { television } \\ \text { Wash } & \text { washer } \\ \text { WH } & \text { water heater } \\ \text { XPS } & \text { extruded polystyrene insulation }\end{array}$





\section{ACKNOWLEDGMENTS}

The authors sincerely thank Tennessee Valley Authority (TVA), for allowing Oak Ridge National Laboratory (ORNL) use of the three unoccupied research homes for this project. A host of trained professionals from TVA, ORNL, and the Electric Power Research Institute (EPRI) worked toward the common goal of developing energy efficiency guidelines for residential construction. Also thanks go to Owens Corning and the Building Science Corporation for their respective inputs to the project. 



\section{EXECUTIVE SUMMARY}

The top four consumers of active energy in residential homes are comfort conditioning, hot water, plug loads and lighting. Comfort conditioning comprises the largest fraction of total use in all three of the Campbell Creek homes. Water heating is the next largest use, but as house efficiency improves, the plug loads exceed hot water usage.

The replacement of a standard electric water heater with a heat pump water heater (HPWH) is a simple yet excellent retrofit option for reducing energy use and utility peak demand. A HPWH dropped the annual energy usage for domestic hot water by $54 \%$ of that by the standard electric water heater. The incremental cost for the HPWH is $\$ 850$ and the simple payback is about $41 / 2$ years. An EcoCute HPWH was field tested and found competitive to the GE HPWH. The EcoCute HPWH uses carbon dioxide gas $\left(\mathrm{CO}_{2}\right)$ as the refrigerant. The EcoCute HPWH has no resistance element or backup heating system. It is designed to always heat with the compressor.

Heat pumps capable of step-change or continuously variable speed control of the blower and compressor can reduce the resistance energy need, the peak demand, and also the cycling losses occurring when the capacity of the heat pump exceeds house load. The conventional single-speed heat pump is sized to satisfy the building's cooling load, which often results in it being undersized for the heating load. Sizing single-speed equipment to heating load results in excessive cycling in the cooling season which, in turn, makes the home humid because the heat pump does not run long enough to adequately dehumidify the conditioned space. Variable-capacity heat pumps address these shortcomings by providing an opportunity to intentionally size systems for the dominant heating load without the adverse effects of cycling or insufficient dehumidification during the cooling season. On an annual basis, the variable capacity system demonstrated an annual savings of $2,989 \mathrm{kWh}$ or $31 \%$ over the baseline single-stage heat pump system.

The variable speed heat pump will also reduce peak demand that occurs on very cold mornings in the Tennessee Valley. The unit assessed in this study, when in over-speed mode, will reduce if not eliminate the use of backup resistance heat during cold winter mornings, which in turn reduces the peak demand on TVA's existing infrastructure.

The summertime washing and drying of clothes often coincides with TVA's daily peak demand occurring in late afternoon. The HPWH demonstrated hot water heating schedules that meet water heating demand and shifted hot water power consumption away from the summer peak period. However, the occupant profile tends to confound a best approach for hot water load management delivered by HPWHs. An occupant profile with lower hot water consumption can shift the power consumption out of the peak summer period into a non-peak period. But for an occupant profile with high hot water consumption, it is difficult to shift hot water energy use out of the summer peak period. Hence, occupancy habits tend to confound a best approach for hot water load management delivered by HPWHs.

The Energy Star front-loading clothes washers are designed to save hot water demand and to use a much higher-speed spin cycle than the conventional top-load clothes washer. They therefore use more electrical energy for the faster spin cycle. However, the higher-speed spin forces more water from the clothes and reduces dryer energy. The demonstrations measured a reduction of 3200 gallons of hot water per year for the Energy Star models. The total kilowatt-hours required for washing clothes including the energy to heat water drops $\sim 58 \%$ for the Energy Star front-load machine over the top-load machine. Considering both washer and dryer loads and the electrical energy to heat water gives a combined savings of about $40 \%$ for laundry.

The largest retrofit energy savings found in the Campbell Creek homes occurred by moving the airhandler and HVAC ducts inside the conditioned space. Putting the HVAC and duct in the living space or 
converting a ventilated attic into a semi-conditioned and sealed attic was effective in recapturing energy lost from the HVAC system. However the material and labor charges for spray foam applications (about $\$ 5 \mathrm{k}$ to $\$ 6 \mathrm{k}$ ) is too high for most homeowners. The field data also revealed the sealing technique could lead to higher attic moisture levels and higher interior moisture levels than measured in the homes equipped with vented attics. The variable speed HVAC system was adjusted to reduce the relative humidity level in the retrofit home to levels observed in the other two homes. There was no indication of mold or material degradation in the spray foam sealed attic or conditioned space during the course of study. The roof sheathing moisture content stayed below $20 \%$ as measured midway between the soffit and ridge by Boudreaux et al. (2013). Also, the relative humidity at the roof sheathing stayed within the ASHRAE 160 design criteria except for a short time during the 2011/2012 winter when the ductwork was not operating in the attic.

The more energy efficient and thermally tight the home, the less is the benefit of setback thermostats. The use of setback thermostats showed no significant performance gains in the Near Zero home having the HVAC system and ducts in the conditioned space. The reverse is true of homes with HVAC and ducts installed in the temperature extremes of an unconditioned attic. Field testing during the summer 2011 for "energy-conscious" and a more conservative "modified comfort" setback schedule yielded daily reduction in heat pump energy of about $24 \%$ and $39 \%$ of that measured in the builder's house (fixed set point at $\left.76^{\circ} \mathrm{F}\right)$. 


\begin{abstract}
Tennessee Valley Authority (TVA) ${ }^{1}$ funded and managed a showcase demonstration in the suburbs of west Knox County, Tennessee. Work started March 2008 with the goal of documenting best practices for retrofitting existing homes and for building new high-efficiency homes. Oak Ridge National Laboratory and the Electric Power Research Institute (EPRI) provided technical support. An analytical base was developed for helping homeowners, homebuyers, builders, practitioners and TVA make informed economic decisions about the materials and incentives necessary to build a new high-efficiency home or retrofit an existing home. New approaches to more efficiently control active energy subsystems and information for selecting or upgrading to Energy Star appliances, changing all lights to 100\% CFLs and upgrading windows to low-E gas-filled glazing yields a 40\% energy savings with neutral cash flow for the homeowner. Passive designs were reviewed and recommendations made for envelope construction that is durable and energy efficient.
\end{abstract}

The Campbell Creek demonstration complements the DOE Building Technologies Program strategic goal. Results of the project demonstrated design approaches that will yield affordable energy efficient homes. The 2010 DOE retrofit goals are to find retrofit packages that attain 30\% whole house energy savings as documented by pre and post Home Energy Rating Scores (HERS). Campbell Creek met these goals.

\title{
1. THE CAMPBELL CREEK HOMES ACTIVE HOUSE DESIGN
}

This report describes both state-of-the-art and advanced active (Section 1) and passive subsystems (Section 2) employed in three homes located in the Campbell Creek community of Farragut in west Knox County, Tennessee. All three houses are two-story, slab-on-grade, framed construction. All homes were unoccupied during the field study but all had simulated occupancy-automated mechanisms replicate the occupancy of a family of three, including opening and closing of the refrigerator door, daily use of the oven, the washing and drying of clothes and personal hygiene (i.e., daily showers). Salient features of the homes are described by Christian et al. (2010). He named the homes by their key purpose in the project as "builder's house," "retrofit house," and the "near zero" energy home. Briefly:

- Builder's house (CC1) — served as a baseline representative of a standard IECC 2006 codecompliant, ${ }^{2}$ all-electric house.

- Retrofit house (CC2) —included modifications that if applied to existing houses would improve the home's energy efficiency. Each modification was evaluated using field data and a computer model benchmarked to the field data.

- Near Zero house (CC3)—similar to the builder's house (CC1) but built using advanced energyefficiency features, including solar electricity and solar hot water.

CC1 and CC2 have approximately 2,400 sq ft of gross footprint. CC3 has a footprint of 2,500 sq ft. It contains a pantry option, used primarily as a mechanical equipment room, which adds $100 \mathrm{sq} \mathrm{ft}$. The three houses are all-electric (with the exception of a gas log fireplace that was not used during field testing). Air-source heat pumps provide comfort conditioning to each home. CC1 and CC2 are adjacent one another with a south-facing orientation; CC3 has a north-facing orientation and is located across the street and a couple of houses down (Fig. 1).

\footnotetext{
${ }^{1}$ TVA Office of Technology Innovation, Energy Efficiency, Power Delivery and Utilization.

${ }^{2}$ The IECC 2006 code is the base from which the HOME Energy Rating Score (HERS) is computed.
} 
Most of the appliances installed in the retrofit home (CC2) and the Near Zero home (CC3) are certified as Energy Star compliant. The appliances in all homes were operated on command by an automated data collection and control code, LabVIEW ${ }^{\circledR}$ by National Instruments. LabVIEW ${ }^{\circledR}$ controlled the scheduling of all appliances based on occupancy profiles established by Hendron and Engebrent (2009). Salient features of the heat pumps field tested in the homes are described in Appendix A. A summary of the building envelope for each home is provided in Appendix B.

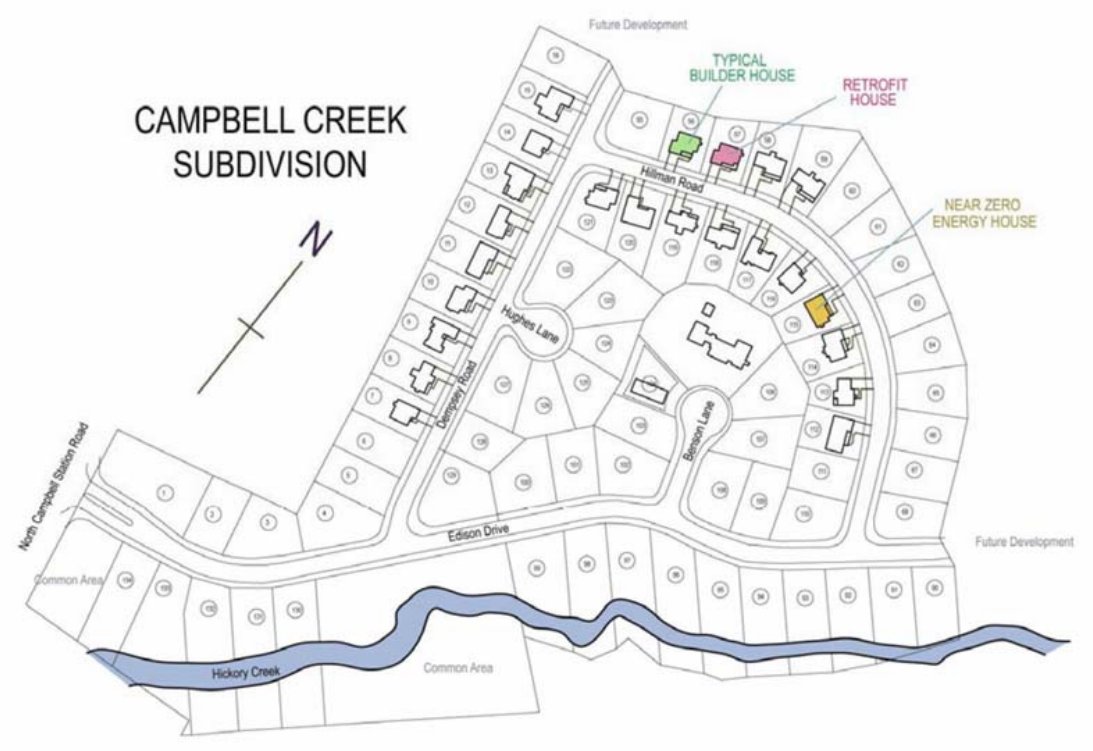

Fig. 1. Map for the layout of CC1, CC2 and CC3 test homes in the Campbell Creek Subdivision.

\subsection{ANNUAL ENERGY CONSUMPTION FOR THE THREE HOMES}

A HERS rater appraised the Campbell Creek homes using the Residential Energy Services Network $\left(\right.$ RESNET $^{\circledR}$ ) software tool (REM/Rate $\left.{ }^{\mathrm{TM}}\right)$; scores are listed in Table 1. HERS scores are also listed using

Table 1. HERS rating, infiltration rates and construction costs for FY 2012

\begin{tabular}{|c|c|c|c|}
\hline Description & Builder's unit (CC1) & Retrofit unit (CC2) & Near zero unit (CC3) \\
\hline HERS $^{1}$ & 101 & 68 & 34 \\
\hline HERS $^{2}$ & 100 & 60 & 30 \\
\hline $\mathrm{ACH}$ at $50 \mathrm{~Pa}$ & 5.7 & 3.4 & 2.4 \\
\hline Duct Leakage & $\begin{array}{l}1^{\text {st }} \text { Floor: } 52 \mathrm{cfm}_{25}(9 \%) \\
2^{\text {nd }} \text { Floor: } 131 \mathrm{cfm}_{25}(16 \%)\end{array}$ & $\begin{array}{l}\text { Attic Sealed Space } \\
\text { Duct: } 60 \mathrm{cfm}_{25} \text { to OD }\end{array}$ & Ducts in Living Space \\
\hline $\begin{array}{c}\text { Construction Costs } \\
\left(\$ / \mathbf{f t}^{2}\right)\end{array}$ & $\$ 102$ & $\$ 106$ & $\$ 141$ \\
\hline
\end{tabular}

\footnotetext{
${ }^{1}$ HERS based on RESNET tool computations.

${ }^{2}$ HERS based on measured energy use Oct. 1, 2013 through Sep. 30, 2012.

${ }^{3}$ Includes the cost of the $2.5 \mathrm{kWp} \mathrm{PV}$ and solar hot water (SHW) systems setup on the near zero house.
}

measured annual energy use with CC1 consumption serving as the base because it was built to IECC 2006 code. These second set of HERS scores benchmark the reasonableness of the estimates used by REM/Rate ${ }^{\mathrm{TM}}$ to predict a home's HERS. All homes were field tested in the mixed-humid climate of East Tennessee. The air exchange rate (ACH) of the envelope and the duct leakage are provided along with the retail cost per square foot for each home. Christian et al. (2010) provide full details of the homes. 
The Campbell Creek field study commenced mid-year in 2009 and continued through 2014. During the course of study, several different makes of air-to-air heat pumps were field tested at the homes. The timeline of each unit's testing is depicted in Fig. 2 to help the reader better perceive subtle differences in annual energy usage. Two time periods are reviewed: October 1, 2011 through September 30, 2012 [2011/2012 Period] and the more current period October 1, 2013 through September 30, 2014 [2013/2014 Period]. After 3 months into time period 2011/2012, the mini-split Mitsubishi SEER 15 system with multi-split indoor air-handlers was replaced with a high-efficiency Carrier Greenspeed ${ }^{\mathrm{TM}}$ heat pump with variable-speed compressor and variable-speed indoor blower. The Carrier system was connected to the existing zoned ductwork originally installed in the retrofit home CC2. Thus the indoor air-handler and ductwork were installed in the semi-conditioned space of the sealed attic in CC2. Salient features of the heat pumps and the problems encountered during testing are further explained in Appendix A.

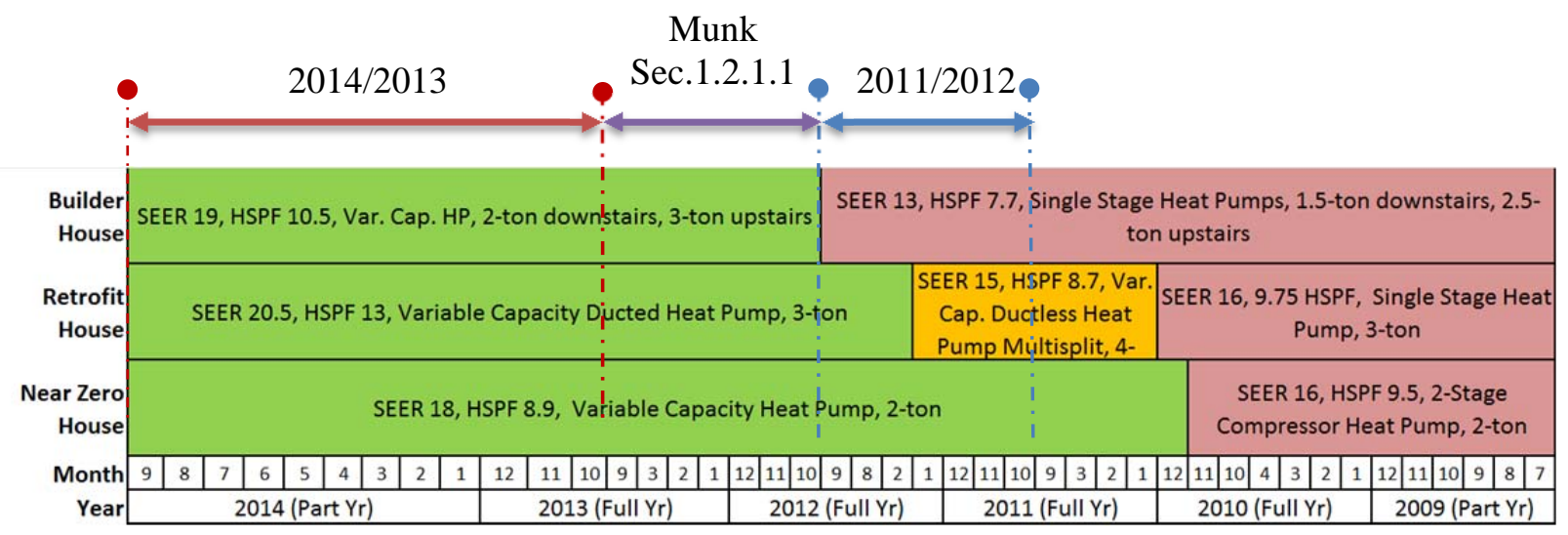

Fig. 2. Timeline for all the heat pumps field tested at the Campbell Creek homes.

The top four energy consumers for all three homes were comfort conditioning, hot water, plug loads and lighting. Comfort conditioning comprised the largest fraction of the total use in all three homes. Water heating is the next largest use in CC1, but plug loads exceed hot water usage in both CC2 and CC3.

\subsubsection{Builder's House (CC1) Review, 2011/2012 and 2012/2013}

The comfort conditioning load was supported by single-stage heat pumps in the builder's house (CC1) during the October 2011 through September 2012 review period. Comfort conditioning was the largest fraction of whole house energy usage, accounting for $40 \%$ of the total for this period. Heating in CC1 was $21 \%$ and cooling load was $19 \%$. Domestic hot water (DHW) was another $19.3 \%$ of the total energy. The annual plug loads (plugs including TV) represented 14.5\%. The lights also represented $14.7 \%$ of the annual use. The dryer was $5 \%$ and the clothes washer represented $0.3 \%$.

In October 2013, four equipment changes were made to the builder's house (CC1). Heaters were adjusted to better simulate occupant load. Energy output from one heater was dropped from $1500 \mathrm{~W}$ to $500 \mathrm{~W}$. The adjustment caused a $326 \mathrm{kWh}$ reduction in plug loads from the 2011/2012 period to the more recent 2012/2013 period. EPRI also installed a demand response relay in CC1 for demonstration of HVAC control during periods of peak utility demand. The standard electric water heater was replaced by a commercially available GE Heat Pump Water Heater (HPWH). Two, variable speed, air-source heat pumps replaced the original SEER 13 single-speed heat pumps in CC1 (Fig. 3). The heat pump retrofit dropped comfort conditioning only $346 \mathrm{kWh}$, a $4.3 \%$ reduction as compared to the heat pump energy measured during the 2011/2012 time period. A control board had been replaced in the heat pump serving the upstairs in CC1 during the 2013/2014 period. The malfunction caused the heat pump to use too much resistance heat, which skewed the energy usage of the heat pump for the 2013/2014 period. Section 1.2.1.1 provides more useful field data for the heat pump retrofit in CC1. It is also suspected that the 
marginal improvement occurred in part because the losses from the duct in the attic predominate and therefore installing a high-efficiency heat pump in an existing home does not yield best potential unless work is done to improve the ductwork housed in the extreme temperatures of the attic.

However, the addition of the GE HPWH dropped the annual energy usage for domestic hot water by $2052 \mathrm{kWh}$, a 54\% reduction in hot water energy use as compared to the standard electric water heater. The incremental cost for the HPWH is about $\$ 850$, and the two time periods demonstrate a simple payback of $4 \frac{1}{2}$ years. See Section 1.2 for more information.

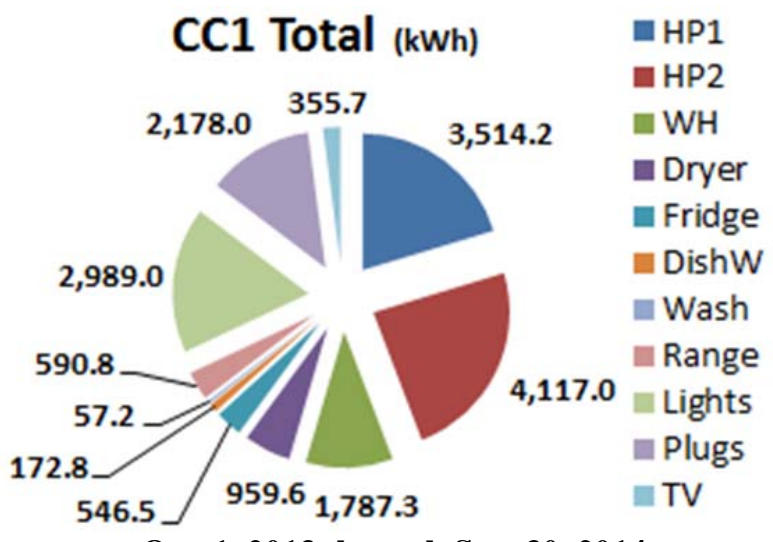

Oct. 1, 2013 through Sep. 30, 2014

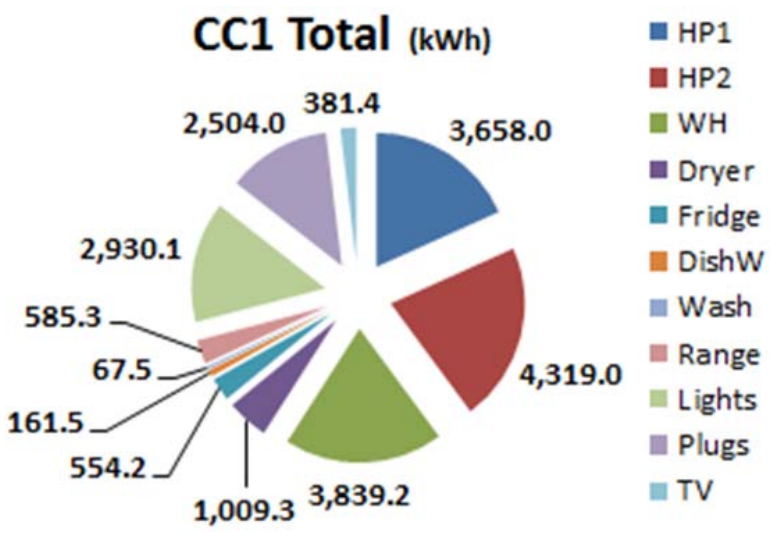

Oct. 1, 2011 through Sep. 30, 2012

Fig. 3. Breakdown of annual energy used by the CC1 home for the time period Oct. 1, 2011 through Sep. 30, 2012 and the time period Oct. 1, 2013 through Sep. 30, 2014.

\subsubsection{Retrofit House (CC2) Review, 2011/2012 and 2012/2013}

The annual energy use for the retrofit home (CC2) was $40 \%$ less than that consumed by the builder's home (CC1) over the October 1, 2011 through September 30, 2012 period. The reduced utility usage yields annually $\$ 680$ of savings for the retrofit home as compared to the builder's home. Energy savings in CC2 are due to improved heat pump efficiency, transforming the attic into a semi-conditioned sealed attic to reduce HVAC duct losses, more energy efficient appliances, compact fluorescent lighting (CFL), more thermally efficient windows and a more air tight envelope.

In the retrofit house (CC2), the comfort conditioning load is $44.9 \%$ of the total consumption and represents the largest use in CC2 during the 2011/2012 period. It is comprised of $23.7 \%$ for space heating and $21.2 \%$ for space cooling. The plug loads (including TV) is $20 \%$, water heating, $10 \%$; lights, $7.6 \%$; and dryer, $6.2 \%$ of the total annual energy use during the 2011/2012 period.

A Mitsubishi multi-split heat pump equipped with a 4-ton condenser and eight air handler units was removed from CC2 and replaced with a variable-speed heat pump featuring independent speed control of the compressor and the indoor blower (Fig. 4). The heat pump replacement occurred 3 months into the 2011/2012 review period. A Sanden EcoCute $\mathrm{CO}_{2} \mathrm{HPWH}$ was installed and made operable at CC2 on August 2012. Energy use for domestic hot water (DHW) in CC2 went up, however, because of previous equipment failures with an earlier installed EcoCute $\mathrm{CO}_{2} \mathrm{HPWH}$. A replacement $\mathrm{HPWH}$ was installed, and comparing the DHW usage in CC1 to CC2 provides a better assessment of the EcoCute $\mathrm{CO}_{2} \mathrm{HPWH}$ as compared to the GE HPWH in CC1 during the 2013/2014 period. The EcoCute $\mathrm{CO}_{2}$ HPWH (Fig. 4, 2013/2014) consumed $123 \mathrm{kWh}$ less energy than the GE HPWH (Fig. 3, 2013/2014). Therefore the EcoCute $\mathrm{CO}_{2} \mathrm{HPWH}$ is competitive with the GE HPWH. One of two heaters used to simulate occupant 
load was also adjusted as done in CC1. The adjustment caused a $240.5 \mathrm{kWh}$ reduction in plug loads from the 2011/2012 period as compared to the more recent 2012/2013 period.

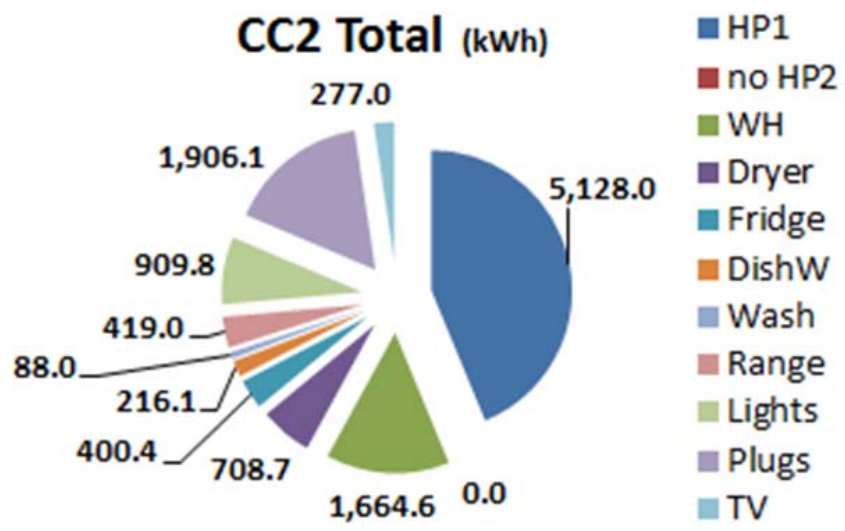

Oct. 1, 2013 through Sep. 30, 2014

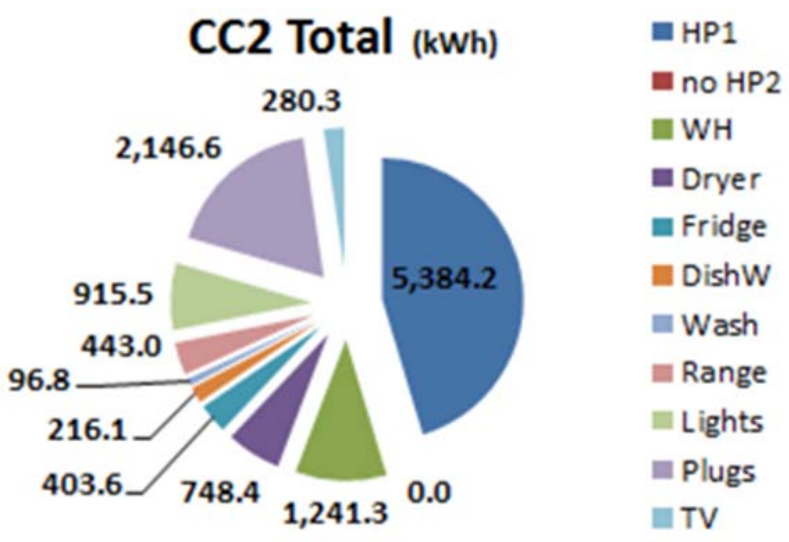

Oct. 1, 2011 through Sep. 30, 2012

Fig. 4. Breakdown of annual energy used by the CC2 home for the time period Oct. 1, 2011 through Sep. 30, 2012 and the time period Oct. 1, 2013 through Sep. 30, 2014.

\subsubsection{Near Zero House (CC3) Review, 2011/2012 and 2012/2013}

A 48\% drop in energy was documented for the near zero home (CC3) as compared to the CC1 builder's home (data for the 2011/2012 timeframe). Including renewable generation by CC3 yielded a 70\% drop in energy as compared to that used by CC1. The energy conservation yields annually $\$ 1,550$ of savings for the near zero home (CC3) as compared to the builder's home (CC1). Savings are due to improved heat pump efficiency, HVAC ducts and air handler in the living space, LED lighting, energy efficient appliances, more airtight and improved thermal envelope, thermally efficient windows and renewable energy generation.

Comfort conditioning was again the largest measured energy draw for the near zero home (CC3), being 35\% of annual nonrenewable use during the 2011/2012 timeframe (Fig. 5). Cooling load made up 20\% and heating load $15 \%$ of the annual use. Water heating was $16.3 \%$ and the electric clothes dryer was measured at $7.3 \%$ of whole house consumption.

CC3 used a 2-ton Daikin heat pump equipped with a two-speed compressor. The Daikin heat pump comfort conditioned CC3 during both time periods displayed in Fig. 5. Unfortunately the variable-speed controller did not function correctly. Daikin representatives visited and confirmed ORNL findings (Munk et al. 2012) that the unit would not modulate but would run at near constant power throughout each duty cycle. The unit was also leaking refrigerant charge and during the visit, and the Daikin representatives added an additional 14 ounces of charge to the system. Apparently the leak was not corrected and the increase in HVAC power usage from 2011/2012 to 2013/2014 is believed due to too low a refrigerant charge over the course of study and in part due to improper modulation control.

Despite the heat pump malfunction, some meaningful results can be gleaned from the 2011/2012 time period for the near zero home (CC3). The Daikin variable-speed heat pump consumed $3601 \mathrm{kWh}$ of electricity to comfort condition CC3 as compared to $7977 \mathrm{kWh}$ of energy used by the builder's house (CC1) for the same time period, the same climate and the same occupancy loading. The key difference is placement of the HVAC system and duct in the living space of CC3 as compared to the extreme temperatures of the attic of CC1. Comfort conditioning energy was more than doubled by the placement of the HVAC and ducts in the attic of the builder's home (CC1). 


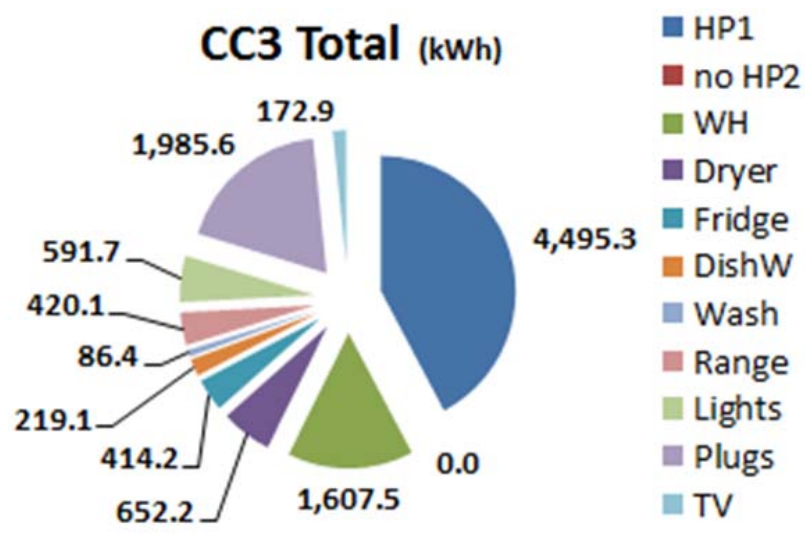

Oct. 1, 2013 through Sep. 30, 2014

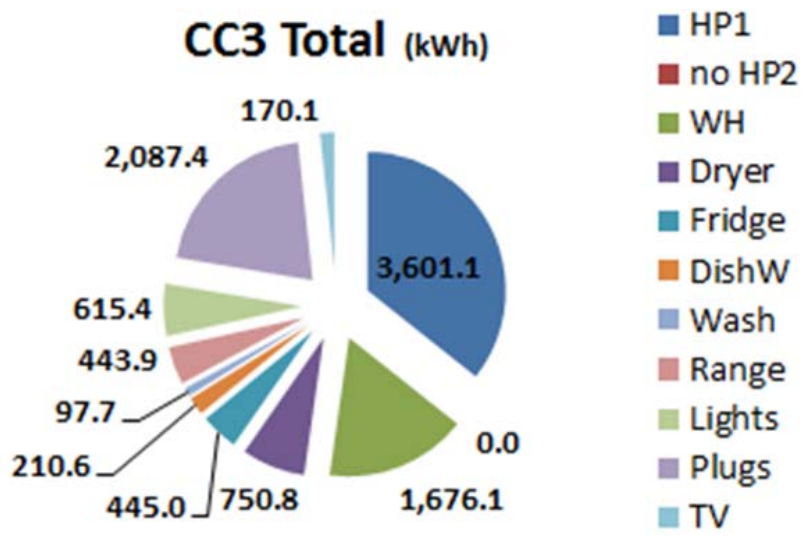

Oct. 1, 2011 through Sep. 30, 2012

Fig. 5. Breakdown of annual energy used by the CC3 home for the time period Oct. 1, 2011 through Sep. 30, 2012 and the time period Oct. 1, 2013 through Sep. 30, 2014.

Again, heaters were used to simulate occupant load, and in CC3 the energy output from one of two heaters was dropped from $1500 \mathrm{~W}$ to $500 \mathrm{~W}$ to better simulate occupant heat loads. The adjustment caused a $101 \mathrm{kWh}$ reduction in plug loads from the 2011/2012 period to the more recent 2012/2013 period.

\subsection{ANNUAL ENERGY CONSUMPTION FOR KEY SUBSYSTEMS IN THE THREE HOMES}

The retrofit house (CC2) demonstrated that envelope air tightness, efficient appliances and air ducts routed through the sealed and semi-conditioned attic produced a 40\% drop in whole house energy for a moderate investment of $\$ 9 \mathrm{k}$. For TVA, the upgrades cut peak demand to half of that measured for CC1 (Table 2). CC3 would also roughly halve that demand. The peak hourly demand for CC1 and CC2 occurred on January 19, 2012 in the early morning hours for CC1 and in the late afternoon for CC2. The load factor is about 0.2 or less for all homes (Table 2). Energy costs for CC3, the most energy efficient of the three houses, totaled about \$319 for the entire year (based on the net energy use of 6,772 kWh which includes the benefits of renewable generation). This averages to an electric bill of about $\$ 40$ per month for a three-bedroom, two-and-a-half-bath house of $2400 \mathrm{sq} \mathrm{ft}$.

Table 2. Annual energy (kWh) report from Oct. 1, 2011 through Sep. 30, 2012

\begin{tabular}{|c|c|c|c|c|c|c|c|c|c|c|}
\hline \multirow[b]{2}{*}{ House } & \multirow[b]{2}{*}{ Total $^{1,2}$} & \multirow[b]{2}{*}{$\mathrm{PV}^{1}$} & \multirow[b]{2}{*}{$\mathrm{Net}^{1}$} & \multirow[b]{2}{*}{$\begin{array}{l}\text { Cost of } \\
\text { Energy }\end{array}$} & \multirow[b]{2}{*}{ PeakHr ${ }^{1}$} & \multirow[b]{2}{*}{ Average $^{1}$} & \multirow[b]{2}{*}{$\begin{array}{c}\text { Load } \\
\text { Factor }^{3}\end{array}$} & \multicolumn{3}{|c|}{ Water Heater } \\
\hline & & & & & & & & MBTUs & kWh/MBTU & $\begin{array}{c}\text { Solar } \\
\text { Fraction }\end{array}$ \\
\hline "CC1 & 1019,883 & 0.00 & 19,883 & $\$ 1,868$ & 12.98 & 2.26 & 0.17 & 11.127 & 345.0 & \\
\hline CC2 & 11,987 & 0.00 & 11,987 & $\$ 1,189$ & 6.46 & 1.36 & 0.21 & 9.747 & 127.4 & \\
\hline CC3 & 10,307 & $3,535.05$ & 6,772 & $\$ 319$ & 6.29 & 1.17 & 0.19 & 9.086 & 184.5 & 0.487 \\
\hline
\end{tabular}

The added first cost of $\$ 9 \mathrm{k}$ for the improvements made to the CC2 home can easily be financed in a 30year low interest rate mortgage that yields a neutral cash flow for the homeowner after incentives. The federal, TVA and State of Tennessee incentives totaled about \$2,250 and the homeowner's out-of-pocket expense drops to $\$ 6,750$. Homeowners are interested in either retrofitting or building new homes to HERS 70 as confirmed by the testimony from Schaad Companies LLC, which constructed the ZEBRAlliance homes. Schaad now offers new homes with HERS score of 75 with no added cost 
premium to the homeowner. Therefore, a homeowner would most likely be willing to bear the moderate investment for retrofits or build a home to HERS 68 specification.

The key systems that yielded the reductions in annual energy (Table 2) are defined in more detail in Table 3 to showcase those subsystems yielding the largest savings for the homeowner. Annual energy consumption for the heat pump, water heater, lights, plug loads, refrigerator, dishwasher, range, clothes washer, and dryer and the subsequent savings (as compared to the CC1 builder's house) are listed in Table 3. The cost of saved energy and the cost of equipment are documented for field data acquired during the 2011/2012 period.

Table 3. Annual energy use, operating costs from October 1, 2011 through September30, 2012 and initial equipment cost

\begin{tabular}{|c|c|c|c|c|c|c|}
\hline Salient feature of equipment & House & $\begin{array}{c}\text { Total } \\
\text { energy } \\
(\mathrm{kWh}) \\
\end{array}$ & $\begin{array}{c}\text { Energy } \\
\text { savings } \\
(\%) \\
\end{array}$ & $\begin{array}{c}\text { Energy } \\
\text { cost } \\
(\$) \\
\end{array}$ & $\begin{array}{c}\text { Cost } \\
\text { savings } \\
(\$)\end{array}$ & $\begin{array}{c}\text { Equipment } \\
\text { costs } \\
(\$) \\
\end{array}$ \\
\hline 13 SEER Single-Speed HP (2 units) & CC1 & 7977 & & $\$ 695.3$ & & $\$ 7,144$ \\
\hline 16 SEER 2-Speed Blower HP (8 AH) & CC2 & 5384 & $33 \%$ & $\$ 469.3$ & $\$ 226.0$ & $\$ 7,144$ \\
\hline 16 SEER, ECM Blower, 2-Speed Comp HP & CC3 & 3601 & $55 \%$ & $\$ 313.9$ & $\$ 381.4$ & $\$ 7,578$ \\
\hline Standard WH & CC1 & 3839 & & $\$ 334.6$ & & $\$ 350$ \\
\hline GE HPWH & CC2 & 1241 & $68 \%$ & $\$ 108.2$ & $\$ 226.4$ & $\$ 1,200$ \\
\hline SHW $^{\mathrm{A}}$ & CC3 & 1528 & $60 \%$ & $\$ 133.2$ & $\$ 201.4$ & $\$ 9,733$ \\
\hline Incandescent Lights & CC1 & 2930 & & $\$ 255.4$ & & $\$ 1,248$ \\
\hline Compact Fluorescent Lights & CC2 & 916 & $69 \%$ & $\$ 79.8$ & $\$ 175.5$ & $\$ 2,131$ \\
\hline LED \& Fluorescent Lights & CC3 & 615 & $79 \%$ & $\$ 53.6$ & $\$ 201.8$ & $\$ 3,754$ \\
\hline \multirow{3}{*}{ Plug load } & CC1 & 2504 & & $\$ 218.2$ & & \\
\hline & CC2 & 2147 & $14 \%$ & $\$ 187.1$ & $\$ 31.1$ & \\
\hline & CC3 & 2087 & $17 \%$ & $\$ 181.9$ & $\$ 36.3$ & \\
\hline Standard Refrigerator & CC1 & 554 & & $\$ 48.3$ & & $\$ 2,299$ \\
\hline Energy Star Refrigerator & CC2 & 404 & $27 \%$ & $\$ 35.2$ & $\$ 13.1$ & $\$ 3,999$ \\
\hline Energy Star Refrigerator & CC3 & 445 & $20 \%$ & $\$ 38.8$ & $\$ 9.5$ & $\$ 3,999$ \\
\hline Standard DW & CC1 & 162 & & $\$ 14.1$ & & $\$ 649$ \\
\hline Energy Star DW & CC2 & 211 & $-30 \%$ & $\$ 18.4$ & $(\$ 4.27)$ & $\$ 1,549$ \\
\hline Energy Star DW & CC3 & 216 & $-34 \%$ & $\$ 18.8$ & $(\$ 4.71)$ & $\$ 1,549$ \\
\hline Standard Range & CC1 & 585 & & $\$ 51.0$ & & $\$ 999$ \\
\hline Hidden Heater Element in Oven & CC2 & 443 & $24 \%$ & $\$ 38.6$ & $\$ 12.4$ & $\$ 1,849$ \\
\hline Hidden Heater Element in Oven & CC3 & 444 & $24 \%$ & $\$ 38.7$ & $\$ 12.3$ & $\$ 1,849$ \\
\hline Standard CW & CC1 & 68 & & $\$ 5.9$ & & $\$ 549$ \\
\hline Energy Star CW & CC2 & 97 & $-43 \%$ & $\$ 8.5$ & $(\$ 2.53)$ & $\$ 1,299$ \\
\hline Energy Star CW & CC3 & 98 & $-45 \%$ & $\$ 8.5$ & $(\$ 2.61)$ & $\$ 1,299$ \\
\hline Energy Star Dryer & CC1 & 1009 & & $\$ 87.9$ & & $\$ 1,099$ \\
\hline Energy Star Dryer & CC2 & 748 & $26 \%$ & $\$ 65.2$ & $\$ 22.7$ & $\$ 1,099$ \\
\hline Energy Star Dryer ${ }^{\mathrm{B}}$ & CC3 & 751 & $26 \%$ & $\$ 65.5$ & $\$ 22.5$ & $\$ 1,099$ \\
\hline
\end{tabular}




\subsubsection{Heat Pump Systems}

Comfort conditioning was the largest consumer of electricity in all three homes. Field data displaying the indoor air temperature confirmed that all homes maintained the same indoor space conditions of $71^{\circ} \mathrm{F}$ in the heating season and $76^{\circ} \mathrm{F}$ in the cooling. All three houses were on average controlled within $\pm 0.3^{\circ} \mathrm{F}$ of each other (Christian el al. 2011). Note that the heat pumps used in the homes were changed throughout the course of the field study (see Fig. 2). The same graphic is also presented in Appendix A along with a historical descriptive of the heat pumps field tested at each home and the problems that occurred with some of the units.

During 2010 the two heat pumps in CC1 were SEER ${ }^{3}$ 13, single-speed air-to-air units. One unit (1.5 ton capacity) serves the first floor of the residence, the other heat pump ( 2.5 ton capacity) maintains comfort for the upstairs living area. For the month of January 2010, the backup resistance heaters consumed 862 kWh of electricity and accounted for $43 \%$ of the space heating energy, which was $28 \%$ of the total house draw. In comparison, the heat pumps in CC2 and CC3 consumed $615 \mathrm{kWh}$ and $455 \mathrm{kWh}$ of resistance heat respectively for the 2010 January period. The heat pumps in CC2 and CC3 each have variable-speed features. CC2 sported a 3-ton SEER 16 heat pump with two-speed ECM ${ }^{4}$ blower and single-speed compressor. CC3 had a 2-ton 18 SEER Daikin ducted heat pump. The unit features a two-speed compressor. Unfortunately, the variable-speed controls for both units did not function correctly and the reported savings in resistance heat is due more to the passive design features in CC2 and CC3.

CC2 had its attic transformed into a semi-conditioned space. The attic was sealed using $\mathrm{CCSPF}^{5}$ overlaid with ocSPF ${ }^{6}$ insulation applied to the underside of the roof deck. The HVAC ductwork was set up for zone control with one zone supplying conditioned air to the first floor and the other zone conditioning the second floor of CC2. Each floor had its own thermostat, which signaled dampers in the ductwork for ondemand comfort conditioning. CC2 used 33\% less energy than did the two single-speed units operating in the builder's house (CC1). The drop in energy is attributed more to the setup of the semi-conditioned attic than to the effect of the two-speed blower. ${ }^{7}$ The semi-conditioned attic recaptured energy lost from the leaky ducts and exploited the lost energy to maintain a more moderate ambient attic temperature, which reduced the overall losses from the heat pump and ducts in CC2. The Daikin heat pump in CC3 had its fan coil installed in a utility closet on the first floor of the home instead of in the attic as in CC2. All ductwork was placed in the conditioned space of the home. The design allowed the unit to use about 55\% less energy than that used by the two single-speed heat pumps in CC1. Miller et al. (2013) has reported that the energy losses from ducts contained in an attic are literally 3 to 4 times the energy losses crossing an attic floor. CC2 and CC3 eliminated these losses by making the duct system part of the conditioned space and thereby dropped the energy consumed by the heat pumps. As caveat, the unit in CC2 was replaced with a Carrier Greenspeed ${ }^{\mathrm{TM}}$ variable-speed air-source heat pump during February 2012. Therefore, part of the energy saving in CC2 is due to the high efficiency variable-speed heat pump (see Appendix A).

\footnotetext{
${ }^{3}$ Seasonal energy efficiency ratio.

${ }^{4}$ Electrically commutated motor drive.

${ }^{5}$ Closed cell spray polyurethane foam insulation.

${ }^{6}$ Open cell spray polyurethane foam insulation.

${ }^{7}$ It was discovered that the indoor fan, which had an ECM drive, always delivered the same airflow even when one of the zones was not calling for conditioning. The error did not allow correct assessment of the ECM blower in CC2.
} 


\subsubsection{Variable-speed heat pump field data}

On October 2, 2012, two Carrier Greenspeed $^{\mathrm{TM}}$ variable-speed air-source heat pumps were installed in CC1. The system consisted of a 3 ton unit for the second floor and a 2 ton unit serving the first floor. The units have a SEER rating of 20.5 and a heating seasonal performance factor (HSPF) rating of 13. The upstairs unit was still placed in the attic as done with the original singlespeed unit. The system design allows the units to operate in efficiency mode or comfort mode. The efficiency mode uses a smart controller to intelligently react to changing outdoor temperatures and the conditions in the house to control blower and compressor speeds for peak efficiency. In comfort mode, occupancy comfort overrides efficiency and the unit runs at lower indoor airflow rates for a warmer supply air temperature; in the cooling mode, the system can reduce the airflow to maintain a more comfortable indoor humidity level (Fig. 6).

The variable-speed heat pumps were sized to the larger heating seasonal load using the procedures documented in Air Conditioning Contractors of America (ACCA) Manual J. The annual heating and cooling energy use of the original single-speed heat pumps is compared in Fig. 6 to the variable capacity heat pumps in both the comfort and efficiency modes. The variable capacity system offers a $25 \%$ reduction in heating season energy use when operating in comfort mode; this increases to $32 \%$ in efficiency mode. The variable capacity heat pumps also show significant energy savings during the cooling season. The variable capacity system offers a $41 \%$ reduction in energy use when operating in comfort mode, and a $44 \%$ reduction in efficiency mode operation. On an annual basis, the variable capacity system operating in comfort mode shows an annual savings of $2,989 \mathrm{kWh}$ or $31 \%$ over the baseline system. When operated in efficiency mode, the energy savings increase to $3,489 \mathrm{kWh}$ or $37 \%$ over the baseline system; see Munk et al. (2012 and 2014) for further information.

The variable-speed compressor has the ability to run at higher speeds in the winter when the outdoor air temperature is cold and at lower speeds in the summer when the air temperature is hotter; this feature reduces the need for supplemental resistance heat. Field data showed a $68 \%$ reduction in resistance heat use over the heating season as compared to that used by the single-speed heat pumps in CC1 (Fig. 7). Intentionally sizing these variable capacity units for the heating season also contributes to the reduction in resistance heat use and shows that the oversizing scheme helps reduce or eliminate the need for supplemental electric resistance heat use in the heating season. This, in turn, reduces peak hourly power draw, which is of particular interest to utilities (Fig. 7).

\subsubsection{Winter electrical peak demand}

During the 3-year study, it was observed that the annual peak load for the Campbell Creek homes occurred on very cold winter mornings. On January 8, 2009, TVA experienced to that date an all-time daily-energy-generation record. The builder's house (CC1) consumed $152 \mathrm{kWh}$ on January 8, 2009; CC2, $113 \mathrm{kWh}$; and CC3, $76 \mathrm{kWh}$. The peak hour for CC1 and CC2 was 7:00 to 8:00 AM. The average $1 \mathrm{~h}$ peak demand on January 8, 2009 for CC1 was $11 \mathrm{kWh}$; CC2, $8.6 \mathrm{kWh}$; and CC3, 7.4 kWh. Therefore, 
retrofits in CC2 cut the peak demand 21\% of the measured peak in CC1 and CC3 cut the peak 32\%. The following year, the peak hourly demand occurred during a cold snap again in January 2010. CC2 had a 33\% lower absolute peak than CC1 and CC3 had a 49\% lower peak.

The variable-speed heat pumps installed in CC1 demonstrate that the electrical resistance heat usage drops as compared to the single-speed units also tested in CC1 (Fig. 7). As stated earlier, the field data showed a $68 \%$ reduction in resistance heat use over the heating season as compared to that used by the single-speed heat pumps in CC1. Therefore, the CC2 and CC3 demonstrations show the potential to literally cut peak demand by $50 \%$ of the CC1 peak demand that occurred with single-speed heat pumps.

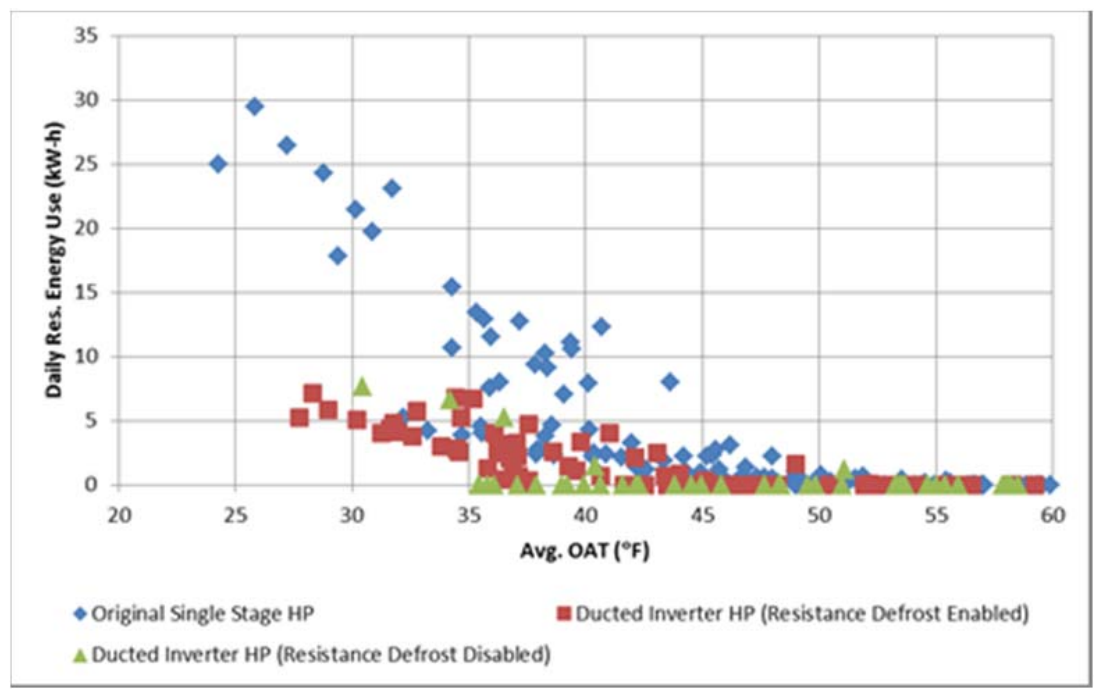

Fig. 7. Resistance heat use in the builder's home (CC1) with the original single-speed heat pumps and also with the Carrier Greenspeed ${ }^{\mathrm{TM}}$ variable-speed air-source heat pumps. Data is from the same time periods shown in Fig. 3.

\subsubsection{Summer electrical peak demand}

The field data for the Campbell Creek homes shows that summer peak demand often coincides with the operation of the clothes washer and dryer. Figure 8 reveals that the peaks are comprised of the clothes dryer, heat pump and hot water usage. The peaks in CC1 and CC2 occur in the late afternoon, generally coinciding with the TVA system summer peak. In CC3 the peak occurred in late morning in July 2010. The peak is around $10 \mathrm{~kW}$ in CC1, $8 \mathrm{~kW}$ in CC2 and $6.5 \mathrm{~kW}$ in CC3. Note that at this time the solar PV system on the CC3 home was generating about $1 \mathrm{~kW}$, so this peak as seen by the grid was really only 5.5 $\mathrm{kW}$, almost half that of CC1. The profiles for each month are illustrated by Christian et al. (2010).

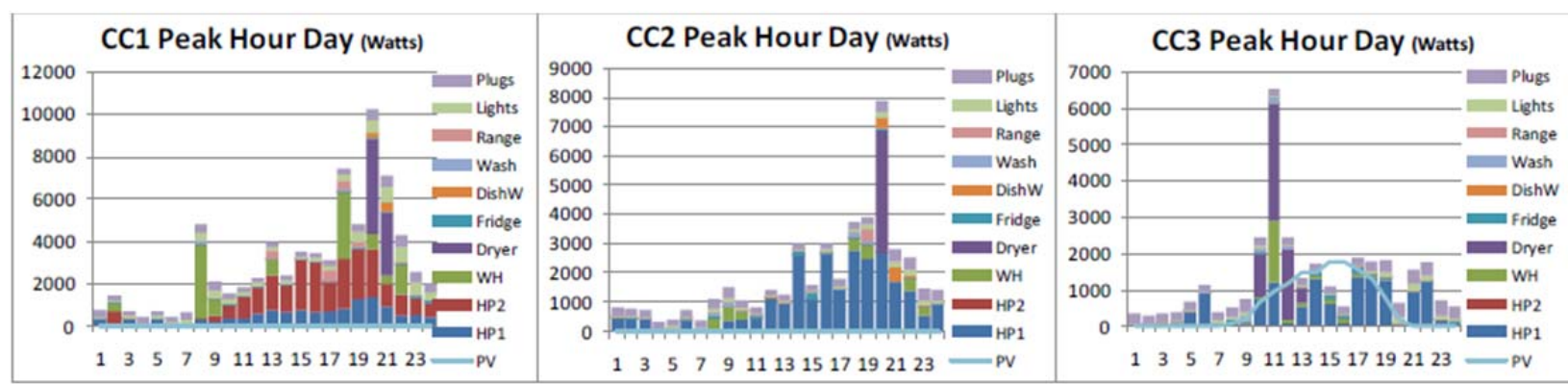

Fig. 8. The $24 \mathrm{~h} \mathrm{~kW}$ profile on the day that had maximum peak hour usage in July 2010. 
Two load-managed DHW temperature profiles were evaluated during the summer to judge whether TVA's summer peak load could be reduced through better time-of-day management for the washing and drying of clothes. The drying of clothes is a simple issue: dry clothes at off-peak periods. However, water heating demand is more elusive. One schedule, Schedule 1, set the hot water tank temperature to $170^{\circ} \mathrm{F}$ from 3 a.m. to 1 p.m. and then to $120^{\circ} \mathrm{F}$ throughout the peak power usage time until 9 p.m. During the nighttime hours, the tank was set to $140^{\circ} \mathrm{F}$. The other schedule, Schedule 2, set the tank temperature to $170^{\circ} \mathrm{F}$ during the night and then reduced it to $150^{\circ} \mathrm{F}$ at 6 a.m. During the peak hours, the set point was lowered to $120^{\circ} \mathrm{F}$ and then raised to $170^{\circ} \mathrm{F}$ after the peak. For both schedules, the HPWH was set to use only the heat pump to meet water heating demand. For both schedules on a non-laundry day, all of the hot water power consumption was successfully shifted from the summer peak period, and the hot water demand was met. However, both schedules consumed more average daily energy than the baseline HPWH because of the energy required for the higher tank temperatures. The higher tank temperature causes the condenser of the HPWH to operate at higher high-side pressures, which, in turn, make the compressor work harder and drops the COP of the HPWH.

On laundry days Schedule 1 consumed 8\% less energy than Schedule 2. For an occupant profile with lower hot water consumption (non-laundry day), schedule 2 totally shifts the power consumption out of the peak summer period into the non-peak hours and with lower energy use than schedule 1 . Conversely, for an occupant profile with higher hot water consumption, schedule 2 not only has higher energy consumption than schedule 1 but also does not meet the primary requirement to shift the water heating load out of the summer peak period. Hence, occupancy habits tend to confound a best approach for hot water load management delivered by HPWHs.

\subsubsection{Thermostat Setback Study}

Experiments were conducted simultaneously in all three homes to document the total energy savings and peak load savings of different thermostat schedules. Theses field tests were conducted from July 1, 2011 to August 31, 2011. The comfort conditioning energy use during the setback times was compared to the set $76^{\circ} \mathrm{F}$ thermostat set point (herein referred to as the control). TVA suggested a flat $78^{\circ} \mathrm{F}$ threshold for energizing the heat pump for comfort cooling. The TVA also suggested a "green" energy-conscious setback and a more conservative "modified" setback schedule (Christian et al. 2011). The energyconscious setback is for the "green" homeowner with thermostat dead bands allowing the indoor temperature to occasionally climb to $85^{\circ} \mathrm{F}$ before a call for cooling. The modified setback is more realistic for occupant comfort with the indoor temperature reaching on occasion $80^{\circ} \mathrm{F}$.

Setting the thermostat up from the $76^{\circ} \mathrm{F}$ control to a fixed $78^{\circ} \mathrm{F}$ in the builder's house (CC1) dropped the measured heat pump energy usage $24 \%$ of the control setting. The setback schedule ("green” energy conscious homeowner) used 39\% less daily heat pump energy than the control, and the modified setback schedule used 30\% less daily heat pump energy than the control (Fig. 9). Christian et al. (2011) noted that the field data was sparse and therefore a model benchmarked against CC1 was used to view the complete cooling season (May till October 19). Computations showed a savings of $47 \%$ if the homeowner adopted the energy-conscious setback schedule over the control (Fig. 9). 


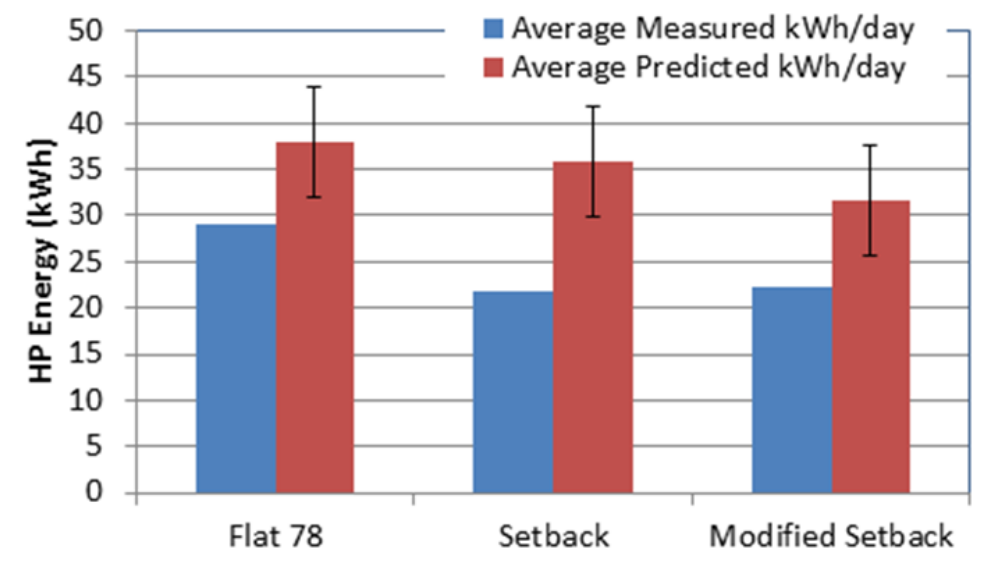

Fig. 9. Measured daily heat pump energy for setback schedules compared to control being a fixed $76^{\circ} \mathrm{F}$ schedule for tests conducted during June 2011.

Setback of the thermostats in CC2 and CC3 had different results than observed in CC1. The fixed $78^{\circ} \mathrm{F}$ schedule used 8\% less daily heat pump energy in CC3 than the control schedule set at $76^{\circ} \mathrm{F}$. The setback schedule used $1 \%$ less daily heat pump energy than the fixed $76^{\circ} \mathrm{F}$ schedule, and the modified setback schedule used $10 \%$ more daily heat pump energy than the fixed $76^{\circ} \mathrm{F}$ schedule. An error analysis of the field measurements showed that the drop in measured energy over the fixed control was less than the uncertainty of measurement and therefore the measurements for CC2 and CC3 are not statistically significant.

Setback of the thermostat saved energy in the builder's home (CC1); however, CC2 and CC3 failed to yield savings by modifying the thermostat's schedule. A key difference is due to the location of the ducts and HVAC. CCI had the ducts and HVAC operating in the extreme temperatures of an unconditioned attic, whereas CC2 and CC3 had the HVAC and ducts in the conditioned space. Increasing the thermostat's cooling set point in CC1 decreased the run time of the heat pump, which, in turn, dropped losses from the duct in an unconditioned space. CC2 and CC3 did not incur these losses, because the ducts and HVAC were inside the conditioned space.

\subsubsection{Water Heater Systems}

Three types of water heating systems were installed at the Campbell Creek homes. A conventional 40 gallon electric water heater with 0.9 energy factor (EF) was installed in the garage of the builder's home (CC1). The retrofit home (CC2) was equipped with a HPWH rated for an EF of 2.35; it remained in operation until August 2012. Afterwards a $\mathrm{CO}_{2} \mathrm{HPWH}$ was installed in CC2's garage for the duration of the field study. As stated earlier, CC3 has a solar hot water (SHW) heating system.

The standard electric water heater in CC1 used the most energy. Both CC2 and CC3 realized energy savings for water heating due in part to the efficient HPWH in CC2 and the solar water heater in CC3. Also CC2 and CC3 are equipped with an Energy Star ${ }^{\circledR}$ dishwasher and clothes washer, which reduced hot water usage about 14 gallons per day as compared to usage by CC1. Data for August 2009 shows the retrofit home (CC2) saved 72\% and CC3's SHW collector saved 88\% of the hot water energy consumed by the builder's home (CC1). In August the SHW collector used only 24 kWh while the HPWH used 57 kWh. 
We observed that the water heating energy use of the HPWH in CC2 was more consistent throughout the year and was about a quarter to a third of the energy use at CC1. The energy use of the SHW system in CC3 follows a similar trend but deviated during the colder winter months.

The SHW collector uses a secondary glycol-water solution to pick up heat from a brazed plate heat exchanger and transfer the heat to the domestic hot water tank through a thermo-siphon heat exchanger attached to the hot water tank. A solar-ready 80 gallon storage tank stores the heated water. A mixing valve is also used to temper the water down to a target temperature of $120^{\circ} \mathrm{F}$. The draw for water is from the bottom of the hot water tank and is in close proximity of the heating element mounted in the tank. The location of the electric heating element increased the water temperature being drawn for heat transfer in the secondary heat exchanger whenever the supply water temperature dropped below $120^{\circ} \mathrm{F}$. Therefore the occasional heat transfer (especially in the winter months) also reduced the transfer of heat from the glycol solution to the hot water tank via the thermo-siphon heat exchanger. In June the power to the resistance heat was removed, which allowed the lower tank temperature to drop below the control set point of $120^{\circ} \mathrm{F}$. This allowed the solar thermal system to run more and at higher efficiencies. The results here indicate that the current control mechanism for the resistance heating element can be improved, and there is need to better design the SHW system for improved winter operation that provides sufficient hot water.

\subsubsection{Lights}

The builder's house (CC1) is illuminated with incandescent bulbs; the retrofit house (CC2), with compact fluorescent light (CFL) bulbs; and the near zero (CC3) home, with a combination of CFL and lightemitting diode (LED) lights. The standard incandescent lamp consists of a tungsten filament inside a gasfilled, sealed glass envelope. The light from an incandescent lamp has a large yellow red component and is therefore highly flattering to the skin. The principal advantages of incandescent lamps are their low cost, instant start and restart, and simple, inexpensive dimming. Fluorescent lamps have almost completely supplanted incandescent lamps in all fields except specialty lighting and residential use because of the human preference for incandescent bulbs that render pleasing skin tones. Recently, LEDs are seeing increased use in residential projects and for specialty applications in commercial projects. They are easy to install, last longer than incandescent or fluorescent lamps, are very efficient, and do not produce nearly as much heat as an incandescent lamp. LEDs are available in a full range of colors, are compact, use very little power, have a fast response and are not affected by repetitive on/off switching.

The field data for lighting show it a substantial part of the total load. The 2,930 kWh of annual energy used for lighting at CC1 was 15\% of the total building load. The energy-efficient CFL lighting package in CC2 reduces the lighting energy 69\% of the CC1 incandescent lights and 79\% of the CC3 combination of CFL and LED lighting.

\subsubsection{Plug Loads}

The plug loads are simulated in each home with a single TV and a pair of baseboard heaters. The plug load savings for CC2 and CC3 as compared to CC1 can be accounted for by the fact that a portion of the simulated load in those homes uses more energy-efficient plug-in lamps (Table 3). 


\subsubsection{Refrigerator}

All of the refrigerators have the same food loading and have the same schedule of simulated door openings (Fig. 10) based on a BA profile for three-person occupancy (Herndon 2009).

The refrigerators in CC2 and CC3 are identical Energy Star units. The unit in CC2 used 27\% less energy than the standard nonEnergy Star unit installed in CC1 (Table 3). The Energy Star unit in CC3 had 20\% less energy than the refrigerator in CC1 over the one year period characterized in Table 3. The refrigerator in CC3 was adapted for waste heat recovery from the condenser and compressor; however, the scheme was not effective since the energy saving dropped as compared to CC2.

\subsubsection{Dishwasher}

The Energy Star dishwasher in CC2 and CC3 actually used over $30 \%$ more energy than the standard (non-Energy Star) model in CC1 (Table 3). The Energy Star model did, however, save on hot water consumption: CC2 used 113 fewer gallons and CC3 used 139 fewer gallons of hot water than consumed by the standard electric water heater in CC1. The CC1 dishwasher consumed $157 \mathrm{Wh}$ per gallon use of hot water. Therefore, the electrical energy required to heat water with the Energy Star dishwashers saves only 15 and $18.5 \mathrm{kWh}$, respectively, and does not compensate for the higher energy use measured for the Energy Star units.

\subsubsection{Clothes Washer}

The Energy Star front-load clothes washers in CC2 and CC3, which have a high-speed spin cycle, used more energy than the conventional top-load clothes washer in CC1, as shown in Table 3. The washers and dryers in all three homes were loaded the same using the BA profiles for the washing and drying of clothes (Hendron 2009). The savings from reduced hot water demand and their capability to force more water from the washed clothes dropped the energy used by the dryer. The annual hot water use by the clothes washers in CC1, CC2, and CC3 was 4784, 1499, and 1558 gallons, respectively. That is a savings of over 3200 gallons of hot water per year for the Energy Star models. The total kilowatt-hours required for washing clothes including energy to heat water is 819, 332, and $342 \mathrm{kWh}$ respectively. The Energy Star front-load machines saved about 58\% of the energy used by a top-load machine selected for CC1. Considering both washer and dryer loads and the electrical energy to heat water gives a combined savings of about $40 \%$ for laundry in CC2 and CC3 as compared to CC1.

\subsubsection{Clothes Dryer}

All homes used the same model dryer during the October 1, 2011 through September30, 2012 field tests. Energy consumed by the dryers was of the order $5 \%$ of the respective house usage (Table 3). However, the data reveals that the dryer tends to dominate the peak load profile not only in the cooling months but also the winter (see Fig. 8). Heat pump dryers appear to be an attractive technology for TVA to encourage; TVA can use time-of-day pricing to encourage off-peak usage of those appliances. Recently Whirlpool Corp. and LG Electronics both introduced new heat pump clothes dryers that are advertised to use $50 \%$ less energy than conventional dryers employing electric resistance heat. 


\section{THE CAMPBELL CREEK HOMES HOUSE DESIGN}

The builder's house (CC1) and the retrofit house (CC2) are 2,351 sq ft, two-story dwellings (Fig. 11). CC3 has a footprint of 2,512 sq ft. Its footprint differs slightly from the other two homes. It contains a mechanical equipment room. Christian et al. (2010) provides complete details of each homes construction. Appendix B provides the salient features for the three different envelope constructions. Herein the key features are described to highlight the important differences among the three homes. The front view of CC1 and CC2 face south; CC3 is further down the street and its front door faces north northeast.

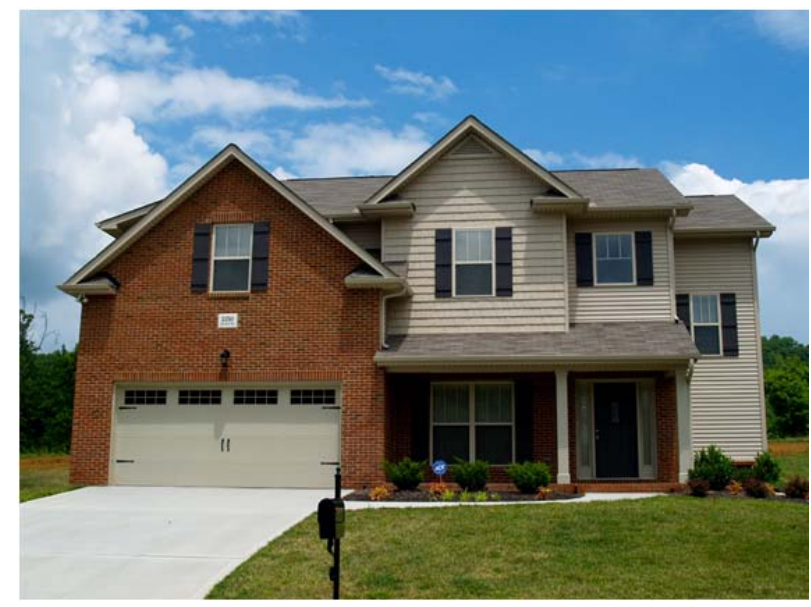

Fig. 11. Front view of the retrofit (CC2) home as viewed from the Hillman Rd.

The floor plan for the first and second floors (Fig. 12) shows the kitchen, breakfast room, great room, dining room, powder room, garage and entrance on the first floor and three bedrooms, bonus room, laundry room, two bathrooms on the second floor. The walls and roof are made of typical $2 \times 4$ frame construction. The walls are rated at R-13. The attic floor is set at R-30. The slab is insulated along the perimeter with $1 \mathrm{in}$. thick by $24 \mathrm{in}$. horizontal R-5 extruded polystyrene on all sides except that adjacent to the garage.

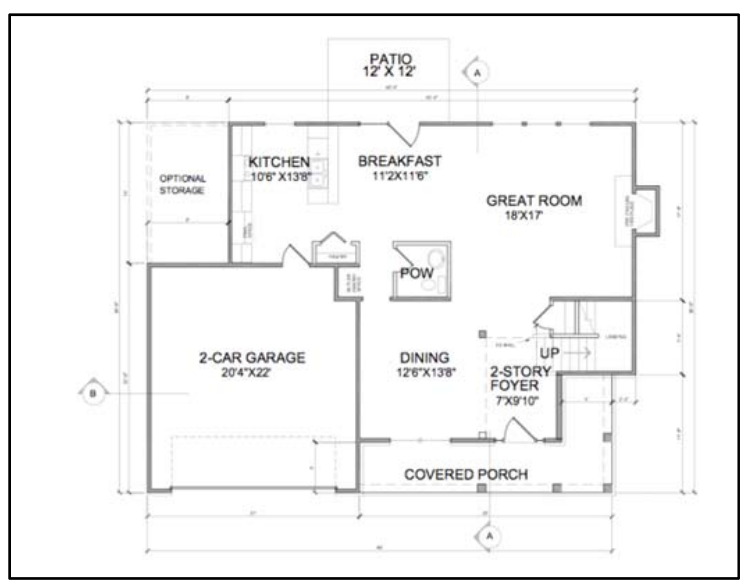

Footprint for the first floor is $1,016 \mathrm{sq} \mathrm{ft}$.

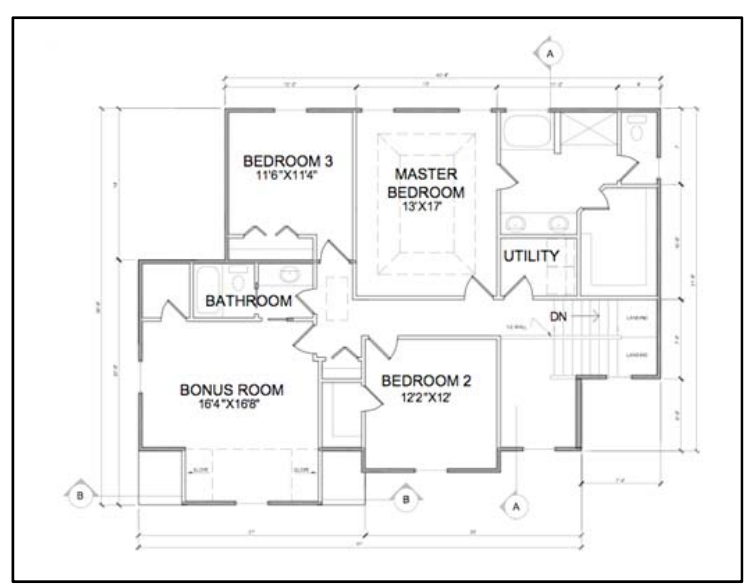

Footprint for the second floor is $1,335 \mathrm{sq} \mathrm{ft}$.

Fig. 12. The floor plans are displayed for the first floor and the second floor of the retrofit (CC2) and the builder's home (CC1). 
The ground level has an open floor plan with most of the structural walls along the perimeter. Note that the structural walls are indicated with a grey tone (Fig. 12). The two-car garage is attached and unconditioned with a conditioned space above. The walls adjacent to the garage, the exterior walls of the garage, and the floor of the bonus room above the garage are insulated. The floor plan for CC3 is very similar with exception of a $100 \mathrm{sq} \mathrm{ft}$ mechanical room on the first floor, and an upstairs layout change of the master bedroom and master bath to accommodate more windows on the south facing wall.

\subsection{WALLS}

The retrofit (CC2) and builder's home (CC1) are constructed with conventional $2 \times 4$ framing. The exterior walls are insulated with R-13 batt insulation with a framing factor of about 0.23 . Vinyl siding was selected for the exterior finish. The siding has a solar absorptance of 0.8 . A few areas of the house, particularly the front wall of the garage and the lower level exterior wall below the front porch, showcase a brick veneer. The veneer is breathable. It contains a 1 in. drainage plane complete with flashing and weep-holes set along the perimeter near the wall's base.

In contract, the wall construction for the CC3 home features optimum-value framing consisting of $2 \times 6$ 's on 24 in. centers. DOWsis ${ }^{\mathrm{TM}}$ is the exterior sheathing. Its R-value is 2.74 and serves as a water-resistive air barrier. All seams were taped for air tightness of the envelope and the exterior walls were further sealed using 1 in. of ccSPF insulation (flash sprayed) against the inside of the DOWsis. The remainder of the wall cavity is filled with Johns Manville spray-in fiberglass insulation.

\subsection{WINDOWS}

The only retrofit to the vertical envelope on the retrofit (CC2) house was an upgrade to windows with overall heat transfer coefficients of U-0.35 and solar heat gain coefficients of 0.34 . No guidance was given to the window installers. In general the windows were installed using best practices. Both caulking and expanding foam were used around the windows prior to installing the drywall.

The CC3 homes used triple-pane windows from Serious Materials. Fabrication of the Serious Materials windows included single-hung triple-layer panes with foam-insulated vinyl frames. Overall heat transfer coefficient was by NFRC standards a U-value of 0.15; the SHGC was 0.26.

\subsection{FOUNDATION}

The setup of the slab-on-grade foundations were the same for CC1 and CC2 homes. Extruded polystyrene board (XPS) of $1 \times 24$ in. dimension was cut and wrapped vertically around the interior edge of the header just below sill plate. XPS was also wrapped horizontally under the slab except on the wall adjacent to the garage. The foam board seams were taped and fastened to the header block every $3 \mathrm{ft}$. The abovegrade wall is attached to the foundation by anchor bolts through a $2 \times 6$ Borate-treated sill plate.

The slab-on-grade foundation for CC3 was better insulated that that for either CC1 or CC2 (Fig. 13).

Contractor Rex Dockery reported that the slab edge was insulated with a $1 \mathrm{in}$. layer of extruded polystyrene along with interior foundation walls being insulated with a continuous layer of 2 in. extruded polystyrene all the way to the top of the footer. XPS was wrapped horizontally under the slab and also along the wall adjacent to the garage (wall adjacent the garage was not insulated in CC1 or CC2). 


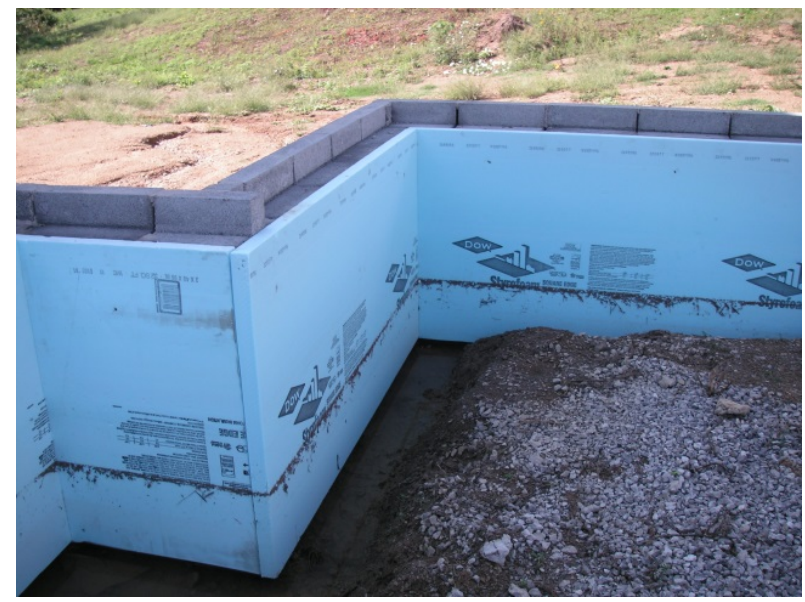

Interior foundation wall insulated with 2 in. XPS

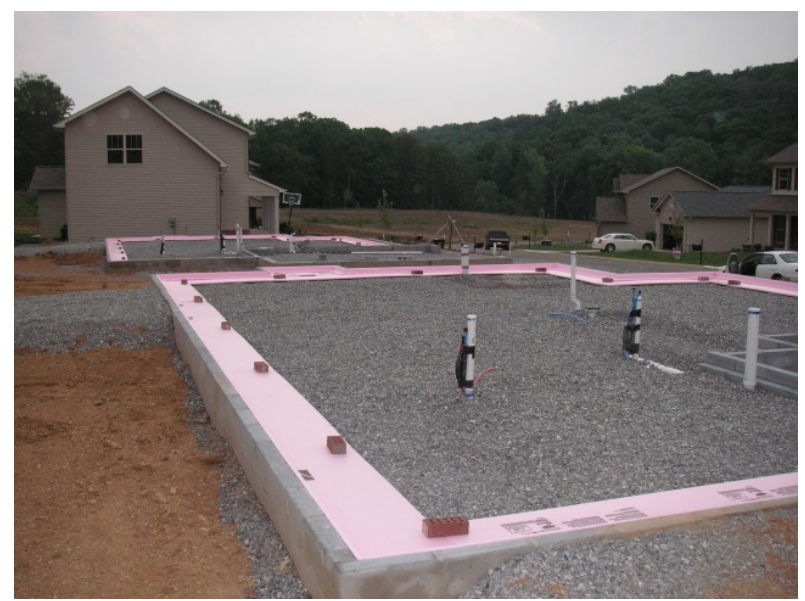

Slab edge insulated with 1 in. XPS

Fig. 13. Foundation insulation applied to the Near Zero house (CC3).

\section{$2.4 \quad$ ATTIC}

The roof trusses forming the attic are pre-engineered and sheathed with $1 / 2 \mathrm{in}$. oriented strand board (OSB) with ply-clips joining the seams. The sheathing for CC3 was the LP Techshield, an OSB board with a perforated radiant barrier attached to the interior side of the sheathing. All roof sheathing was covered with \#30 asphalt-impregnated roofing paper prior to direct nailing asphalt shingles. The attic in CC1 and CC3 was designed with soffit and ridge vents set at a vent area to footprint area of 1:300. The attic for the retrofit (CC2) home was sealed with 2 in. XPS blocking along the soffits and insulated with BioBased ${ }^{\circledR}$ ccSPF insulation. The underside of the roof decks were insulated with $1 \mathrm{in}$. of ccSPF and then topped with about 5.5 in. of ocSPF for a total thermal insulation of about R-30.

\subsubsection{The Semi-Conditioned Attic in CC2 (Retrofit House)}

Jackson et al. (2014) and Boudreaux et al. (2013) have conducted a thorough study of the sealed attic concept, and the interested reader is referred to their work for more information.

The attic of the retrofit home was encapsulated using spray polyurethane foam insulation. The encapsulation included (as previously discussed in Section 1.2.1) placing 2 in. of XPS blocking along the soffits and sealing the soffit, gable, and ridge vents with BioBased $^{\circledR}$ CCSPF insulation. Roughly a 1 in. thickness of ccSPF was also applied to the underside of the roof deck (Fig. 14), and after it thoroughly dried, about 5 to 6 in. of ocSPF was added to yield a total thermal resistance of R-30. Originally an attempt was made to use a blown fiber insulation to top off the ccSPF and reduce cost of the sealed attic. Two separate attempts were made to add blown fiber insulation rather than the ocSPF. However, the materials did not

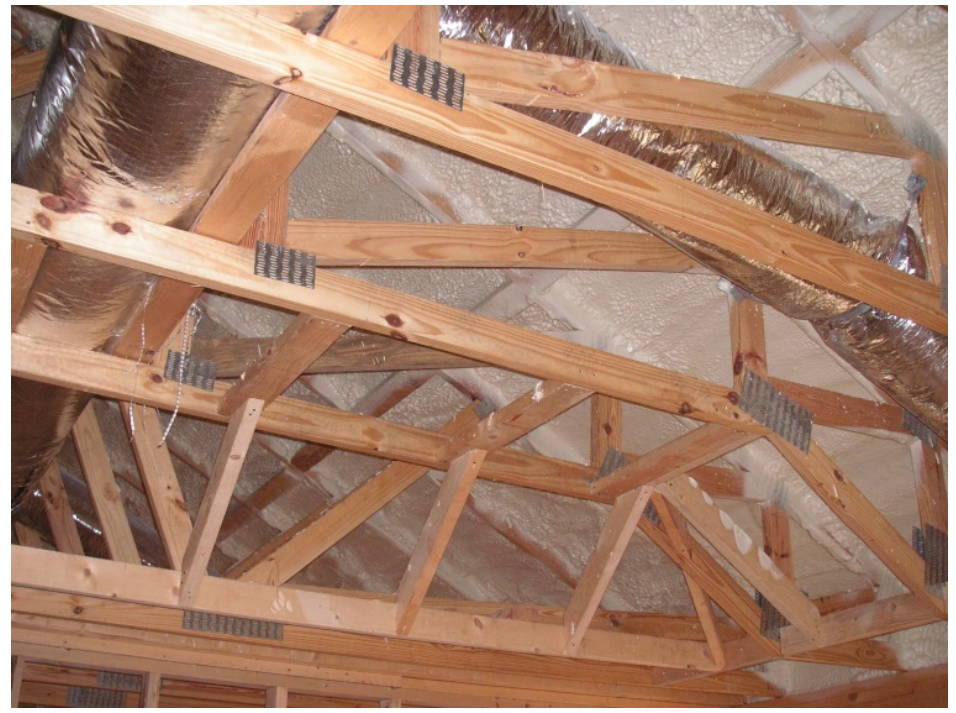

Fig. 14. CC2 sheathing with 1 in. of ccSPF insulation. 
adequately adhere to the ccSPF nor adequately cover the interior layer of ccSPF insulation.

The encapsulation essentially brings the attic and therefore the ducts and HVAC unit into the conditioned space of the building. Lost comfort conditioning from leaky ducts is captured and exploited to make the attic into a semi-conditioned space. Therefore, no insulation was placed on the attic floor.

Jackson et al. (2014) reported the anomalous finding of higher indoor humidity levels in the retrofit home (CC2) as compared to either CC1 or CC3. Both CC1 and CC3 homes had their attics ventilated to 1:300. Initial review focused on the heat pump system in CC2 to check its dehumidification performance. The unit, an Amana 3-ton SEER 16 unit was replaced with a mini-split Mitsubishi SEER 15 system with 8 indoor units (4.75 tons total) and one outdoor unit rated at 4 tons capacity (Christian et al. 2011). Christian reported that the average indoor humidity in CC2 for the month of June 2011 was 52.5\%, compared to 50.3\% in CC1. For July 2011, Christian reported an average indoor RH in CC2 of 56.4\% compared to $46.1 \%$ in CC1 and $46.8 \%$ in CC3. The observation shows that it was more humid in CC2 relative to CC1 and CC3. It was reasoned that the continuously operating fans of the Mitsubishi indoor units were evaporating the condensate on the indoor unit coils into the conditioned space during thermostat setback experiments. Again in August 2011, the relative humidity in CC3 was 45\%, 44.3\% in CC1, and $56.8 \%$ in CC2.

As the field study progressed, the decision was made to replace the Mitsubishi heat pump in CC2. On January 16, 2012 a Carrier Greenspeed unit capable of variable-speed control of the indoor blower and compressor was put into operation for comfort conditioning the retrofit home (CC2). Boudreaux et al. (2013) however found in CC2 and in four other homes with sealed attics compared to four control homes with vented attics, that the attic and interiors were more humid, on average, in the homes with sealed-attic construction as compared to homes with vented attics.

The ORNL researchers ruled out "solar driven moisture" as a significant contributor to the increased moisture in CC2; see Jackson et al. (2014). "Solar driven moisture” was suggested by the building community as the explanation for the migration of moisture through or around a shingle roof (Building Science Corp 2003). Rather, according to ORNL research, the higher moisture in the sealed attic home is due in part to the reduced sensible cooling loads for CC2 because of the sealed attic. While on the other hand, the home's internal sources of moisture generation (e.g., cooking, showers, etc.) remain the same. Therefore, the ratio of sensible to latent heat [i.e., sensible heat ratio (SHR)] in the home drops and puts more dehumidification burden on the heat pump evaporator. Additionally, excess moisture that enters a vented attic is removed by the vents. However, the sealed attic eliminates this option because the soffit, gable, and ridge vents have been sealed with foam.

Finally, it is very difficult to seal an attic because access is limited especially if the roof contains hip roof construction. Recent research by Parsons et al. (2013) has shown that attics are difficult to make air-tight and moisture from the outdoor ambient can leak into the unvented attic. There is expected to be some connection of the attic to the outside although it will be much smaller than the connection of a vented attic. A guarded blower door measurement was performed on the retrofit home that supported this conclusion, showing 336 CFM@50Pa of leakage through the roof. This is about 23\% of the whole house infiltration, which was measured to be 1443 CFM@50Pa (Salonvaara et al. 2013). Based on the LBL effective leakage area, the whole house leakage area is $77 \mathrm{in.}^{2}$ (Sherman and Dickerhoff 1998). This amounts to about $18 \mathrm{in}^{2}$ of leakage area in the sealed attic roof. This means that there is some amount of outside air infiltration/exfiltration between the sealed attic and exterior.

However, the moisture content of the roof sheathing and other wood framing in the attic in CC2 has stayed below $20 \%$. No mold or material damage was found during a visual inspection of the system. Also, 
the relative humidity at the roof sheathing has stayed within the ASHRAE 160 design criteria except for a short time during the 2011/2012 winter.

ORNL's position regarding the sealed attic is the need for more thorough study to provide climate specific best practices. Additionally, other alternatives should also be considered to bring ducts into the conditioned space both in new construction and for retrofits in mixed-humid climates. Comfort conditioning energy was cut in half by placing the HVAC and ducts in the living space of the Near Zero house as compared to having the HVAC and ducts in the attic of the builder's home. 


\section{CONCLUSIONS}

Results of the field data show it very feasible to build new homes and retrofit existing homes that will use less than half the energy consumed by a conventional IECC (2006) code compliant house. In the Tennessee Valley, a homeowner can install a cost-effective retrofit package for a typical new home like CC1 (3 bedroom, 2.5 bath, $2400 \mathrm{sq} \mathrm{ft}$ ) that has a predicted 42\% energy savings and achieves neutral cash flow based on electricity rates of $\$ 0.093 / \mathrm{kWh}$, a 10 -year mortgage at $6 \%$ interest, and available 2010 federal, state, and utility incentives. The homeowner's daily energy costs could feasibly drop from about $\$ 5$ per day to $\$ 1$ per day or even less.

\subsection{KEY DEDUCTIONS FOR PASSIVE ENERGY SAVINGS}

The largest retrofit energy savings found in the Campbell Creek homes occurred by moving the airhandler and HVAC ducts inside the conditioned space. Converting the ventilated attic of CC2 into a semiconditioned and sealed attic was effective in recapturing energy lost from the HVAC system. However the material and labor charges for spray foam applications (about $\$ 5 \mathrm{k}$ to $\$ 6 \mathrm{k}$ ) is too high for most homeowners. The field data also revealed the sealing technique could lead to higher attic moisture levels and higher interior moisture levels than measured in the CC1 and CC3 homes equipped with vented attics. However, there was no indication of mold or material degradation in the attic or conditioned space of the retrofit house (CC2). A section of foam was removed from both the north and south roofs. The roof deck measured less than $10 \%$ moisture content at both locations, and there was no visual indication of OSB degradation. Reducing the air leakage of the home's envelope also played a significant role in reducing whole building energy.

Field tests conducted to observe the benefits from setback thermostats showed no significant performance gains in both CC2 and CC3 homes that had the HVAC air handler and ductwork in the conditioned space. The reverse was true for the builder's home (CC1). "Energy-conscious" and more conservative "modified comfort" setback schedules yielded daily reduction in heat pump energy of about $24 \%$ and $39 \%$ of that measured in the control (fixed set point at $76^{\circ} \mathrm{F}$ ) because the heat pump run time in CC1 dropped and reduced duct losses from the HVAC and ducts in the unconditioned attic.

\subsection{KEY DEDUCTIONS FOR ACTIVE ENERGY SAVINGS}

The top four active energy consumers are comfort conditioning, hot water, plug loads and lighting. Comfort conditioning comprises the largest fraction of the total use in all three homes. Water heating is the next largest use in CC1 but plug loads exceed hot water usage in both CC2 and CC3.

\subsubsection{Comfort Conditioning}

Comfort conditioning by heat pumps was the largest consumer of electricity in all three homes. All homes were on average controlled within $0.3^{\circ} \mathrm{F}$ of each other. The two heat pumps in CC1 were single-speed airto-air units. The heat pumps in CC2 and CC3 each had variable speed features but the variable-speed controls for both units did not functioned correctly. Therefore the reductions in heat pump energy (Table 3) are attributed more to the setup of the building envelopes where the ducts are placed inside the conditioned space and the envelope made air tight.

On October 2, 2012, Carrier Greenspeed ${ }^{\mathrm{TM}}$ variable-speed air-source heat pumps were installed in the builder's home (CC1). The variable speed heat pumps performed significantly better than did their singlespeed predecessors. Variable capacity heat pumps were sized to the heating load to exploit their variablespeed capacity to match cooling load and reduce cycling losses. Losses that are inherent to single-speed equipment sized to heating load rather than cooling load. 
On an annual basis, the variable capacity system (operated in comfort mode, Section 1.2.1.1) shows an annual savings of 2,989 $\mathrm{kWh}$ or $31 \%$ drop below the baseline system. When operated in efficiency mode (see Section 1.2.1.1), the energy savings increase to $3,489 \mathrm{kWh}$ or $37 \%$ over the baseline system.

The variable-speed compressor reduces the need for supplemental resistance heat. Field data showed a $68 \%$ reduction in resistance heat use over the heating season as compared to that used by the single-speed heat pumps in CC1. Sizing the variable capacity units intentionally to the heating load also contributes to the reduction in resistance heat use. As result the variable speed systems reduce the peak hourly power draw that typically occurs on a very cold morning. Therefore implementing variable-speed heat pumps will dramatically reduce the utility providers' peak power demand with little required change needed by the providers' infrastructure.

\subsubsection{Hot Water}

The energy savings for water heating reflect the more efficient HPWH in CC2 and the solar water heater in CC3 but also the measured 14 gallon reduction in hot water needed to wash clothes and dishes with the Energy Star $^{\circledR}$ appliances in CC2 and CC3 that are not in CC1.

The replacement of a standard electric water heater with a HPWH dropped the annual energy usage for domestic hot water by $54 \%$ of the hot water energy use for the standard electric water heater. The incremental cost for the HPWH is about $\$ 850$ and the simple payback is about $4 \frac{1}{2} 2$ years.

The Energy Star front-load clothes washers in CC2 and CC3 have a much higher-speed spin cycle than conventional washers. The CC2 and CC3 washers used more energy than the conventional top-load clothes washer in CC1, but the savings from reduced hot water demand and their capability to force more water from the washed clothes resulted in dryer energy savings. The annual hot water use by the CC1, CC2, and CC3 clothes washers was 4784, 1499, and 1558 gallons, respectively. That is a savings of over 3200 gallons of hot water per year for the Energy Star models. The total kilowatt-hours required for washing clothes including the energy to heat water is 819 , 332, and $342 \mathrm{kWh}$ respectively, a $~ 58 \%$ savings for the Energy Star front-load machine over the top-load machine. Considering both washer and dryer loads and the electrical energy to heat water gives a combined savings of about $40 \%$ for laundry in CC2 and CC3 compared with CC1.

\subsubsection{Lighting}

The field data for lighting show it a substantial part of the total load; it being about $15 \%$ of the load. The more efficient CFL lighting in CC2 and CFL plus LED lighting in CC3 saved 69\% and 79\% of the energy consumed by the incandescent lighting installed in the builder's house (CC1). CC3 was equipped with a combination of compact fluorescent (CFL) and LED lights. As the cost of fixtures for LED lights drop, the LED will dominate the residential and commercial markets. 


\section{REFERENCES}

Boudreaux, P., S. Palin, and R. Jackson. 2013. Moisture Performance of Sealed Attics in the MixedHumid Climate, ORNL/TM-2013/525, Oak Ridge National Laboratory.

Building Science Corporation. 2003. Unvented Toofs, Hot-Humid Climates, and Asphalt Roofing Shingles, Research Report 0306, February 2003.

Christian, J., P. Boudreaux, T. Gehl, J. New, and R. Dockery. 2010. Tennessee Valley Authority's Campbell Creek Energy Efficient Homes Project: 2010 First Year Performance Report July 1, 2009August 31, 2010, ORNL/TM-2010/206, Oak Ridge National Laboratory.

Christian, J., P. Boudreaux, T. Gehl, and J. New. 2011. Tennessee Valley Authority's Campbell Creek Research Homes: Summer 2011 Performance Report, ORNL/TM-2012/51, Oak Ridge National Laboratory.

Hendron, Robert, and Cheryn Engebrent. 2009. Building America Research Benchmark Definition, updated December 2009 (current version), NREL/TP-550-47246, http://www.eere.energy.gov/buildings/building_america/pdfs/40968.pdf Golden, Colo.: National Renewable Energy Laboratory.

(IECC) International Energy Conservation Code, 2006.

Jackson, R.K., P. R. Boudreaux, J. D. Munk, A. C. Gehl, C. T. Lyne, and W. Odukomaiya. 2014. Tennessee Valley Authority’s Campbell Creek Research Homes project: FY 2013 Annual Performance Report October 1, 2012 - September 30, 2013, ORNL/TM-2014/159, Oak Ridge National Laboratory.

Miller, W. A., A. Desjarlais, and M. LaFrance. 2013. "Roof and Attic Design Guidelines for New and Retrofit Construction of Homes in Hot and Cold Climates," in Thermal Performance of the Exterior Envelopes of Buildings, XII, proceedings of ASHRAE THERM XII, Clearwater, FL, December 2013.

Munk, J., A. Gehl, and R. Jackson. 2012. Performance of Variable Capacity Heat Pumps in a Mixed Humid Climate, ORNL/TM-2012/17, Oak Ridge National Laboratory.

Munk, J., A. Odukomaiya, R. Jackson, and A. Gehl. 2014. Residential Variable-Capacity Heat Pumps Sized to Heating Loads, ORNL/TM-2013/581, Oak Ridge National Laboratory.

Parsons, G., and M. Drzyzga. 2013. "Insulating and Air Sealing Low-Pitch Residential Attic Spaces: Cost-Effectiveness Evaluation,” in Thermal Performance of the Exterior Envelopes of Buildings, XII, proceedings of ASHRAE THERM XII, Clearwater, FL, December 2013.

Salonvaara, M., A. Karagiozis, and A. Desjarlais. 2013. "Moisture Performance of Sealed Attics in Climate Zones 1 to 4," in Thermal Performance of the Exterior Envelope of Whole Buildings XII International Conference. Clearwater Beach, FL.

Sherman, M., and D. Dickerhoff. 1994. “Air-tightness of US Dwellings,” in Proceedings of 15thAIVC Conference, Buxton, UK, 1: 225-234. 
APPENDIX A. HISTORICAL TIMELINE FOR HEAT PUMPS FIELD TESTED AT THREE HOMES IN CAMPBELL CREEK SUBDIVISION 



\section{APPENDIX A. HISTORICAL TIMELINE FOR HEAT PUMPS FIELD TESTED AT THREE HOMES IN CAMPBELL CREEK SUBDIVISION}

The Campbell Creek field study commenced mid-year in 2009 and continued through 2014. During the course of study, several different makes of air-to-air heat pumps saw service at the demonstrations. The timeline of each unit's testing is depicted in Fig. A.1 and is described briefly for full identification.

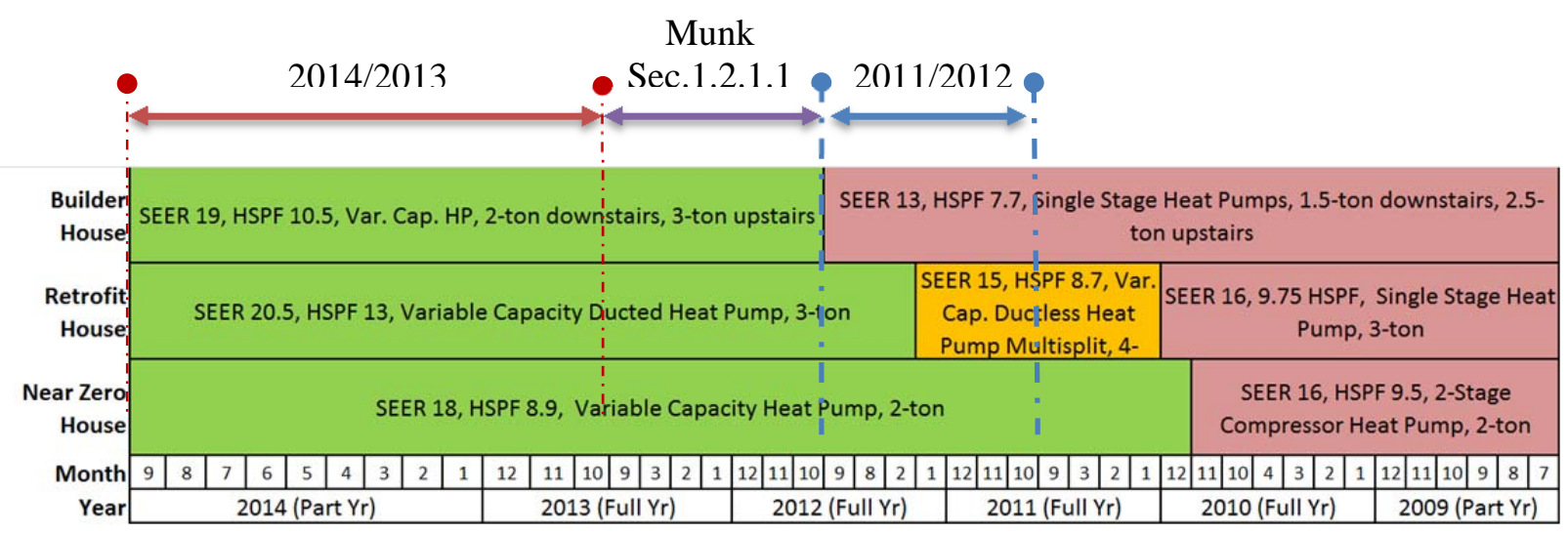

Fig. A.1. Timeline for all the heat pumps field tested at the Campbell Creek homes.

\section{A.1. HEAT PUMPS TESTED IN THE BUILDER'S HOUSE (CC1)}

At the start of testing the heat pumps installed in the builder's home (CC1) were Amana SEER 13 singlespeed heat pumps with a total capacity of 4 refrigerant tons. The second floor of CC1 was equipped with a 2.5-ton SEER-13, 7.7-HSPF unit with $4.75 \mathrm{~kW}$ of backup resistance heat. The unit was installed in the attic and was used to comfort condition the second floor. A similar Amana heat pump but of smaller capacity (1.5-ton) was installed in the unconditioned garage of CC1. It conditioned the first floor of CC1. The second Amana unit had the same SEER-13 and 7.7-HSPF ratings and the same $4.75 \mathrm{~kW}$ of resistance backup heat as the other unit serving the upstairs.

On October 2, 2012, Carrier Greenspeed ${ }^{\mathrm{TM}}$ variable-speed air-source heat pumps were installed in CC1. The Greenspeed ${ }^{\mathrm{TM}}$ unit is capable of variable speed compressor and indoor blower operation. The system consists of a 3 ton upstairs unit and a 2 ton downstairs unit. The units have a SEER rating of 20.5 and a HSPF rating of 13. A control board had been replaced in the heat pump serving the upstairs in CC1 during the 2013/2014 period. The malfunction caused the heat pump to use too much resistance heat which skewed the energy usage of the heat pump for the 2013/2014 period.

\section{A.2. HEAT PUMPS TESTED IN THE RETROFIT HOUSE (CC2)}

An Amana heat pump of 3-ton capacity was installed in the retrofit home (CC2) at the start of field testing, Table A.1. The unit is rated at SEER 16 and HSPF of 9.5. The indoor blower is a two-speed ECM drive. The compressor is conventional single-speed technology. The indoor air-handler and ducts were installed in the attic, which was setup as a semi-conditioned sealed attic using spray polyurethane foam insulation. The HVAC ductwork was setup for zone control with one zone supplying conditioned air to the first floor and the other zone conditioning the second floor of CC2. Unfortunately the variable-speed controls for the ECM blower did not function correctly with the home's thermostat. Also the original intent was to install an Amana heat pump that had a two-speed compressor; it was single-speed. Therefore the unit basically defaults to the Amana heat pumps used in CC1 from July 2009 through about December 2010, Table A.1. 
During the month of January 2011, ORNL replaced the Amana 3-ton SEER 16 unit with a mini-split Mitsubishi SEER 15 system that included 8 indoor units; total evaporator capacity was 4.75-tons. The outdoor unit was sized at 4-tons of capacity. Refrigerant lines for the individual units were run through exterior walls and along either the garage or the backside of the house to the branch boxes on the back wall of the garage. Data was collected on the Mitsubishi system from January 2011 to January 2012.

Soon after the installation of the multi-split system, reduced field data showed that some of the smaller rooms were being over-conditioned. This was caused by a small amount of continuous refrigerant flow to all of the indoor units when the outdoor unit was running regardless of whether they were calling for heat. Continuous operation of the indoor fans compounded the issue and generated enough heat in some rooms to exceed the set point. The indoor fans were disabled when not actively heating per the manufacturer's recommendation. Based on the measured data, the multi-split system was predicted to use $40 \%$ more energy in the heating season and 16\% more energy in the cooling season than the baseline single-speed system, Munk, Gehl and Jackson (2012).

On January 16, 2012 ORNL again replaced the heat pump in the retrofit home (CC2). The Mitsubishi mini-split system was replaced with a high-efficiency Carrier Greenspeed ${ }^{\mathrm{TM}}$ heat pump with variablespeed compressor and variable-speed indoor blower. The Carrier system was connected to the existing zoned ductwork originally installed in the retrofit home. Thus the indoor air-handler and ductwork were installed in the semi-conditioned space of the sealed attic in CC2.

\section{A.3. HEAT PUMPS TESTED IN THE NEAR ZERO HOUSE (CC3)}

The walls of the thermal envelope for the Near Zero house (CC3) were 2 by 6 constructions. The additional 2-in of wall space filled with insulation made the envelope more thermally resistant to heat gains and losses than the other two homes. Therefore capacity of the heat pump was downsized to match the estimated load for CC3. An Amana two-stage heat pump was installed and setup to comfort condition two zones comprised of the first floor and the second floor in CC3. ORNL discovered from the data that a thermostat change-out done to provide remote control actually prevented the compressor from operating in high-capacity mode for most of the 2009-2010 winter.

During December 2010, ORNL replaced the Amana two-stage heat pump with a variable capacity Daikin unit rated at SEER 18. The Daikin unit was ducted and was 2-ton capacity. The heat pump features a twospeed compressor and ECM fan motor, Table A.1. During the 2013/2014 test period, the variable-speed controller did not function correctly. Daikin representatives visited and confirmed ORNL findings (Munk 2012) that the unit would not modulate but would run at near constant power throughout each duty cycle. The unit was also leaking refrigerant charge and during the visit, the Daikin representatives added an additional 14 ounces of charge to the system. Apparently the leak was not corrected and the increase in HVAC power usage from 2011/2012 to 2013/2014 is believed due to too low a refrigerant charge over the course of study and in part due to improper modulation control. 


\section{APPENDIX B. SALIENT FEATURES OF THE BUILDING}

ENVELOPES 



\section{APPENDIX B. SALIENT FEATURES OF THE BUILDING ENVELOPES}

The Campbell Creek field study commenced mid-year in 2009 and continued through 2014. The thermal envelopes of the 3 homes remained consistent during the course of study. Several different makes of airto-air heat pumps saw service at each demonstration; see Appendix A. Table B.1 provides the salient features of the envelope for each home.

\begin{tabular}{|c|c|c|c|}
\hline Component & Builder's House (CC1) & Retrofit House (CC2) & Near Zero House (CC3) \\
\hline \multicolumn{4}{|l|}{ Foundation } \\
\hline Footing & $\begin{array}{l}\text { 24-in by 8-in } \\
\text { concrete footing }\end{array}$ & $\begin{array}{l}\text { 24-in by 8-in } \\
\text { concrete footing }\end{array}$ & $\begin{array}{l}\text { 24-in by 8-in } \\
\text { concrete footing }\end{array}$ \\
\hline Slab-on-grade & $\begin{array}{c}\text { 4-in concrete over vapor } \\
\text { barrier over } \\
\text { 4-in crushed stone }\end{array}$ & $\begin{array}{c}\text { 4-in concrete over vapor } \\
\text { barrier over } \\
\text { 4-in crushed stone }\end{array}$ & $\begin{array}{l}\text { 4-in concrete over } \\
\text { vapor barrier over } \\
\text { 4-in crushed stone }\end{array}$ \\
\hline Waterproofing & 0.006-in vapor barrier & 0.006-in vapor barrier & 0.008-in vapor barrier \\
\hline Interior insulation & $\begin{array}{l}\text { 1-in XPS continuous } \\
\text { around slab edge }\end{array}$ & $\begin{array}{l}\text { 1-in XPS continuous around } \\
\text { slab }\end{array}$ & $\begin{array}{l}\text { 1-in XPS continuous } \\
\text { around slab and } 2 \text {-in XPS } \\
\text { continuous around footing }\end{array}$ \\
\hline \multicolumn{4}{|l|}{ Wall } \\
\hline Interior sheathing & Gypsum board & Gypsum board & Gypsum board \\
\hline Framing & $2 \times 4$ studs at $16 "$ o.c. & $2 \times 4$ studs at $16 "$ o.c. & $2 \times 6$ studs at $24 " 0 . c$. \\
\hline $\begin{array}{l}\text { Insulation } \\
\left(\mathrm{h} \cdot \mathrm{ft}^{2} \cdot{ }^{\circ} \mathrm{F} / \mathrm{Btu}\right)\end{array}$ & $\begin{array}{l}\text { R-13: Single Face } \\
\text { FG Batt }\end{array}$ & $\begin{array}{l}\text { R-13: Single Face } \\
\text { FG Batt }\end{array}$ & $\begin{array}{l}\text { R-22: BioBased ccSPF (1-in) } \\
\text { and spray fiber (4.5-in) }\end{array}$ \\
\hline Exterior sheathing & OSB (7/16-in) & OSB (7/16-in) & $\begin{array}{l}\text { DOW SIS (R-2.7) } \\
\text { Polyisocyanurate with } \\
\text { Fiber Sheathing }\end{array}$ \\
\hline Weather resistive barrier & HouseWrap $®$ (58 Perm) & HouseWrap $®$ (58 Perm) & DOW SIS (0.03 Perm) \\
\hline Cladding & $\begin{array}{l}\text { Brick Veneer and } \\
\text { Lap Vinyl Siding } \\
(\mathrm{SR}=0.20)\end{array}$ & $\begin{array}{l}\text { Brick Veneer and } \\
\text { Lap Vinyl Siding } \\
(\mathrm{SR}=0.20)\end{array}$ & $\begin{array}{l}\text { Brick Veneer and } \\
\text { Lap Vinyl Siding } \\
\quad(\mathrm{SR}=0.20)\end{array}$ \\
\hline \multicolumn{4}{|l|}{ Windows } \\
\hline Glazing & $\begin{array}{c}\text { Double, low-E, gas filled } \\
\text { U-0.58; SHGC } 0.58\end{array}$ & $\begin{array}{c}\text { Double, low-E, gas filled } \\
\text { U-0.34; SHGC } 0.33\end{array}$ & $\begin{array}{c}\text { Triple, low-E, gas filled } \\
\text { U-0.14; SHGC } 0.27\end{array}$ \\
\hline \multicolumn{4}{|l|}{ Roof } \\
\hline Framing & $\begin{array}{l}\text { Truss (2 by } 4) \\
\text { at } 24 \text {-in o.c. }\end{array}$ & $\begin{array}{c}\text { Truss (2 by } 4) \\
\text { at } 24 \text {-in o.c. }\end{array}$ & $\begin{array}{l}\text { Truss (2 by } 4 \text { ) } \\
\text { at } 24 \text {-in o.c. }\end{array}$ \\
\hline $\begin{array}{l}\text { Attic floor insulation } \\
\left(\mathrm{h} \cdot \mathrm{ft}^{2} \cdot{ }^{\circ} \mathrm{F} / \mathrm{Btu}\right)\end{array}$ & $\begin{array}{l}\text { Blown fiberglass } \\
\text { (R-25.5) }\end{array}$ & - & $\begin{array}{c}\text { Blown fiberglass } \\
\text { (R-49) }\end{array}$ \\
\hline Attic ventilation & $\begin{array}{l}\text { Soffit and ridge vents } \\
(1: 300)\end{array}$ & Sealed & $\begin{array}{l}\text { Soffit and ridge vents } \\
(1: 300)\end{array}$ \\
\hline $\begin{array}{l}\text { Roof deck insulation } \\
\left(\mathrm{h} \cdot \mathrm{ft}^{2} \cdot{ }^{\circ} \mathrm{F} / \mathrm{Btu}\right)\end{array}$ & - & $\begin{array}{c}\text { R-30: 2-in ccSPF plus 4-in } \\
\text { ocSPF }\end{array}$ & - \\
\hline Sheathing & OSB & OSB & $\begin{array}{l}\text { OSB w/ LP TechShield } \\
\text { Radiant Barrier }\end{array}$ \\
\hline Underlayment & 15\# asphalt-impregnated felt & 15\# asphalt-impregnated felt & 30\# asphalt-impregnated felt \\
\hline Cladding & $\begin{array}{c}\text { Asphalt Shingle } \\
(0.25 \text { solar reflectance) }\end{array}$ & $\begin{array}{c}\text { Asphalt Shingle } \\
\text { (0.25 solar reflectance) }\end{array}$ & $\begin{array}{c}\text { Asphalt Shingle } \\
\text { (0.15 solar reflectance) }\end{array}$ \\
\hline \multicolumn{4}{|l|}{ Floor Frame } \\
\hline Truss & 18-in truss & 18-in truss & 20-in truss \\
\hline
\end{tabular}





\section{INTERNAL DISTRIBUTION}

1. Philip R. Boudreaux

2. Anthony C. Gehl

3. Roderick K. Jackson

4. Giannate Khowailed

5. William (Bill) Miller

6. Jeffrey Munk

7. Joshua New
8. Martin Keller

9. Johnney Greene

10. Patrick Hughes

11. ORNL Office of Technical Information and Classification

\section{EXTERNAL DISTRIBUTION}

12. Samuel DeLay, Tennessee Valley Authority, Technology Innovation Energy Utilization, Mail Code: BR5N 206-C, 1101 Market Street, Chattanooga, TN 37402

13. Drew Frye, Tennessee Valley Authority, Technology Innovation Energy Utilization, Mail Code: BR5N 206-C, 1101 Market Street, Chattanooga, TN 37402

14. David Dinse, PO Box 317, Wildwood GA 30757

15. Tom Key, Electrical Power Research Institute, Inc. 942 Corridor Park Boulevard, Knoxville, TN 37932-3723

16. Dr. Ronald Domitrovic, Electrical Power Research Institute, Inc. 924 Corridor Park Blvd. Knoxville, TN 37932-3723

17. Philip Enquist, Skidmore, Owings \& Merrill LLP, 224 S. Michigan Avenue, Suite 1000, Chicago, IL 60604, USA 
